\title{
Toxic effects of metal oxide nanoparticles and their underlying mechanisms
}

\author{
Yanli Wang ${ }^{1,2}$, Lin Ding ${ }^{1}$, Chenjie Yao ${ }^{1}$, Chenchen $\mathrm{Li}^{1}$, Xiaojun Xing ${ }^{1}$, Yanan Huang ${ }^{1}$, Tianjiao Gu ${ }^{1}$ \\ and Minghong $\mathrm{Wu}^{1 *}$
}

\begin{abstract}
Nanomaterials have attracted considerable interest owing to their unique physicochemical properties. The wide application of nanomaterials has raised many concerns about their potential risks to human health and the environment. Metal oxide nanoparticles (MONPs), one of the main members of nanomaterials, have been applied in various fields, such as food, medicine, cosmetics, and sensors. This review highlights the bio-toxic effects of widely applied MONPs and their underlying mechanisms. Two main underlying toxicity mechanisms, reactive oxygen species (ROS)- and non-ROS-mediated toxicities, of MONPs have been widely accepted. ROS activates oxidative stress, which leads to lipid peroxidation and cell membrane damage. In addition, ROS can trigger the apoptotic pathway by activating caspase-9 and -3 . Non-ROS-mediated toxicity mechanism includes the effect of released ions, excessive accumulation of NPs on the cell surface, and combination of NPs with specific death receptors. Furthermore, the combined toxicity evaluation of some MONPs is also discussed. Toxicity may dramatically change when nanomaterials are used in a combined system because the characteristics of NPs that play a key role in their toxicity such as size, surface properties, and chemical nature in the complex system are different from the pristine NPs.
\end{abstract}

Keywords: metal oxide nanoparticles, bio-toxicity effect, nanotoxicology, underlying mechanism

\section{INTRODUCTION}

Over the past few decades, nanotechnology has been considered as one of the most potential technologies [1]. With the rapid development of nanotechnology, metal oxide nanoparticles (MONPs) have been widely used in various fields, such as electronic devices, cosmetics, paints, additives in food, and biological and medical systems
[2-6]. However, their potential risks to human health and the environment have attracted the attention of scientists worldwide. Recently, many studies have suggested that MONPs exert adverse effects on various organs leading to serious health problems [7-11]. Therefore, study on the biological safety of these NPs is a very essential and blossoming field, which mainly focuses on investigating the potential adverse effects of NPs and their potential toxicity mechanisms [12-15]. Systematical study on the bio-effects of MONPs and their mechanisms not only protects human health and the environment, but also contributes to maximizing the application of nanomaterials in various fields safely.

In this review, we discuss the bio-toxicity of several commonly used MONPs (titanium oxide $\left(\mathrm{TiO}_{2}\right) \mathrm{NPs}$, zinc oxide ( $\mathrm{ZnO}) \mathrm{NPs}$, and iron oxide (IO) NPs), and highlight the toxicological mechanisms of these NPs. Studies on the toxic effects of these NPs focus on both in vitro and in vivo investigations. MONPs can easily pass through the cell membrane and directly induce cell death in vitro. Furthermore, MONPs cause damage to the organs after entering the body in vivo. Currently, the toxicity mechanism is mainly divided into reactive oxygen species (ROS)and non-ROS-mediated toxicities. ROS-mediated toxicity is one of the most recognized toxicity mechanisms of MONPs. ROS activates oxidative stress, which results in cell membrane damage, protein denaturation, DNA damage, and mitochondrial membrane permeability change. Besides, ROS can activate caspase- 9 and -3 , and trigger the apoptotic pathway. In addition, researchers have also discovered several non-ROS-related mechanisms including the effect of released ions, excessive accumulation of

\footnotetext{
${ }^{1}$ Institute of Nano-chemistry and Nano-biology, Shanghai University, Shanghai 200444, China

${ }^{2}$ Harvard School of Public Health, Harvard University, Boston, Massachusetts, 02115, USA

*Corresponding author (email: mhwu@shu.edu.cn)
} 
NPs on the cell surface, and combination of NPs with specific death receptors. Furthermore, we summarize combined toxicity and its influence when MONPs are mixed in complex systems. Once the NPs combine with other substances, their physicochemical characteristics such as size, surface properties, and chemical nature would change, influencing their potential toxicity. However, previous studies are mostly limited to single NPs in comprehending the risk of NPs. Hence, we should pay more attention to the effect of combined toxicity. This review is aimed at improving the performance of MONP application in various fields and reducing their potential hazard.

\section{TOXIC EFFECTS OF MONPs}

MONPs display potential utility in many applications, including food, cosmetics, nanomedicines, solar cells, and catalytic agents. Among these $\mathrm{MONPs}, \mathrm{TiO}_{2}, \mathrm{ZnO}$, and IO NPs have received the most attention owing to their wide application and unique physical and chemical properties [16-18]. Large-scale manufacturing and consumer utilization of MONPs pose increasing risks to human health and the environment. Thus, systematic bio-safety study of MONPs is highly warranted, including the bio-effects in biological systems and mechanism of toxicology.

\section{Titanium dioxide nanoparticles}

$\mathrm{TiO}_{2}$, a white odorless crystalline powder, is deemed a low or even non-toxic material [19-21]. $\mathrm{TiO}_{2} \mathrm{NPs}$ are manufactured worldwide and commonly used in many fields, such as paints, cosmetics, photosensitive materials, and food additives $[22,23]$. With the development of nanomedicine, the application of $\mathrm{TiO}_{2} \mathrm{NPs}$ in biomedicine as carriers in drug and gene delivery has become very common $[24,25]$. According to the National Nanotechnology Initiative of America, $\mathrm{TiO}_{2}$ NPs are the most widely produced NPs in the world [24]. With large-scale manufacturing and utilization, humans are facing more exposure to $\mathrm{TiO}_{2} \mathrm{NPs}$, resulting in toxic interactions. Therefore, the potential hazards of $\mathrm{TiO}_{2}$ NPs on human health attract people's concern. There have been many studies on the bio-toxicity of $\mathrm{TiO}_{2} \mathrm{NPs}$ [26].

\section{In vitro studies}

Some studies showed that the toxicity of $\mathrm{TiO}_{2} \mathrm{NPs}$ is relatively low [24,27]. Pujalte et al. [27] reported that compared with the toxicity of $\mathrm{ZnO}$ and CdS NPs in IP15 (glomerular mesangial) and HK-2 (proximal tubule epithelial) cell lines, $\mathrm{TiO}_{2}$ NPs showed no obvious cell damage even at higher concentrations $\left(>20 \mu \mathrm{g} \mathrm{cm}^{-2}\right)$. The
$\mathrm{IC}_{50}$ (defined as concentration which induces $50 \%$ cell mortality) values for $\mathrm{ZnO}$ and $\mathrm{CdS}$ were $3.04 \pm 0.07$ and $4.85 \pm 0.06 \mu \mathrm{g} \mathrm{cm}^{-2}$, respectively. Only slight toxicity was observed for $\mathrm{TiO}_{2}$ NPs at concentrations of 80 and 160 $\mu \mathrm{g} \mathrm{cm}{ }^{-2}$. However, other studies showed that $\mathrm{TiO}_{2} \mathrm{NPs}$ exhibited significant cytotoxicity [22,28]. Butler et al. [29] reported that $\mathrm{TiO}_{2} \mathrm{NPs}$ were endocytosed by Salmonella typhimurium, which caused mutagenicity in TA98 and TA1537 strains. Valdiglesias et al. [30] studied the cytotoxic and genotoxic potential of $\mathrm{TiO}_{2} \mathrm{NPs}$. They indicated that $\mathrm{TiO}_{2}$ NPs induced the reduction of mitochondrial dehydrogenase activity and mitochondrial membrane potential in human lymphocytes, leading to cell apoptosis. Wang et al. [31] pointed out that microtubules was destroyed after treatment of $4 \mathrm{~T} 1$ cells with 50 and $200 \mathrm{mg} \mathrm{L}^{-1}$ of $\mathrm{TiO}_{2} \mathrm{NPs}$ (Fig. 1a-h).

Many factors, such as size, shape, surface chemical property, dispersion, dosage, and time have effects on toxicity evaluation of NPs [32-34]. Zhang et al. [35] studied the toxicity of 5 and $32 \mathrm{~nm} \mathrm{TiO}_{2}$ NPs in murine MC3T3-E1 preosteoblasts. The results showed that cells treated with $5 \mathrm{~nm}$ $\mathrm{TiO}_{2}$ NPs stimulated lactate dehydrogenase (LDH) release, mitochondrial damage, and apoptosis more significantly compared with those treated with $32 \mathrm{~nm} \mathrm{TiO}_{2} \mathrm{NPs}$. In addition, size-dependent cytotoxicity effect was observed in RAW264.7 (murine macrophage) and BEAS-2B (human bronchial epithelial) cells after $2 \mathrm{~h}$ incubation with different sizes of $\mathrm{TiO}_{2} \mathrm{NPs}$ [36]. These results indicate that the toxicity of $\mathrm{TiO}_{2} \mathrm{NPs}$ is size-dependent. Several other studies showed that testing conditions, such as dispersion of NPs, might have a great impact on cytotoxicity. Magdolenova $e t$ al. [24] compared two kinds of $\mathrm{TiO}_{2} \mathrm{NPs}$ with different stabilities and agglomeration states. They demonstrated that the dispersion possessing better stability showed severe cytotoxicity compared with the dispersion with agglomeration. Besides, Thomas et al. [25] also obtained a similar result.

Interactions between the cells and NPs, including cellular uptake, subcellular localization, and metabolism present the most primitive fundamental phenomenon, which are very important for the study of NPs toxicity. Wang et al. [37] studied the sub-cellular location of $\mathrm{TiO}_{2}$ nanotubes $\left(\mathrm{TiO}_{2}-\mathrm{NTs}\right)$ in neural stem cells. It is reported that $\mathrm{TiO}_{2}-$ NTs can be internalized into the cells after $24 \mathrm{~h}$ of incubation. Furthermore, they also found that $\mathrm{TiO}_{2}-\mathrm{NTs}$ passed through the nuclear pore complex entering the cell nucleus after $48 \mathrm{~h}$ of co-incubation [38]. Besides, they also investigated endocytosis, exocytosis, and the related mechanisms [39]. It is indicated that both endocytosis and exocytosis 

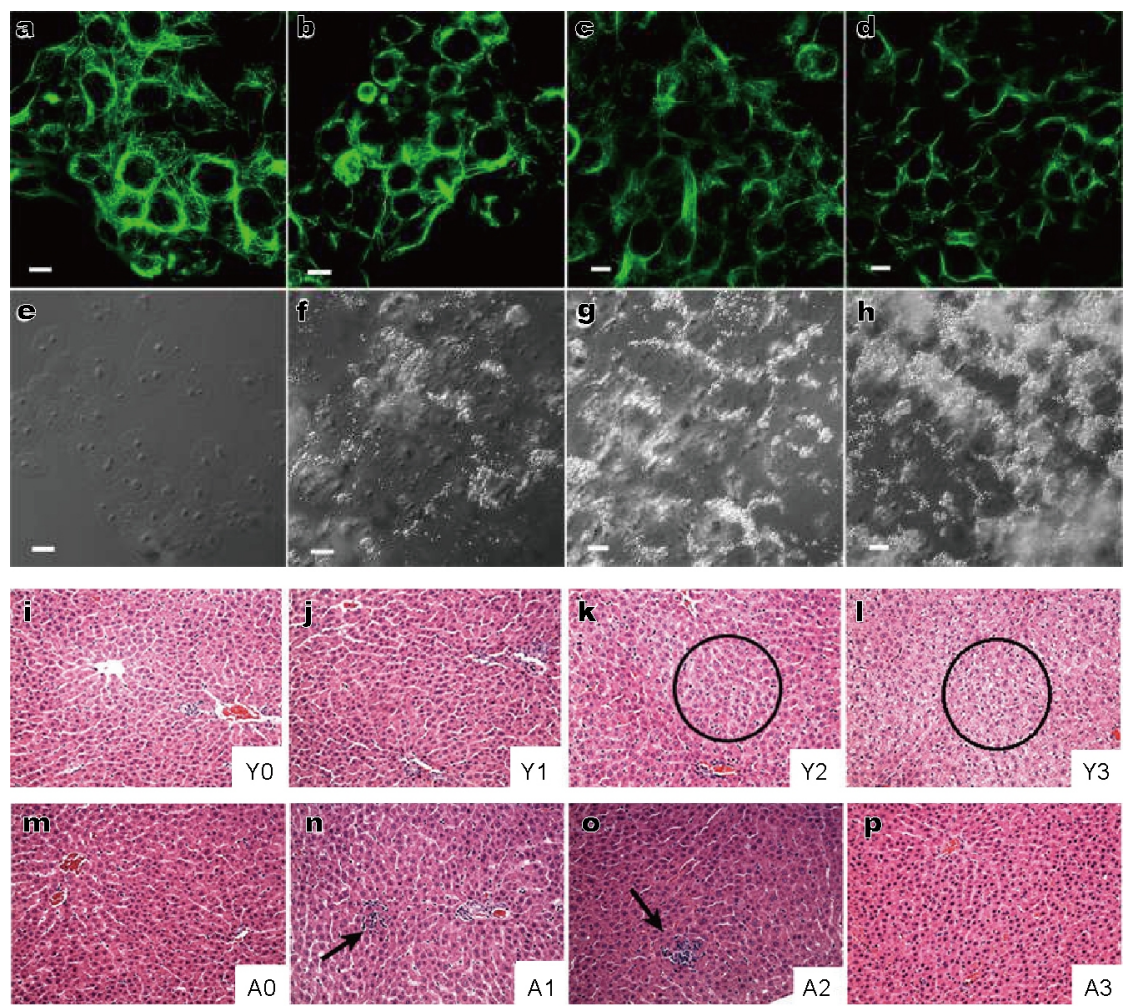

Figure 1 (a-h) Microtubule dynamics following exposure to $\mathrm{TiO}_{2} \mathrm{NPs}$ using immunofluorescence staining: (a-d) fluorescence images of 4T1 cells examined under a laser scanning confocal microscope and (e-h) phase contrast images of $4 \mathrm{~T} 1$ cells. (a, e) Control group (treated in the absence of $\mathrm{TiO}_{2} \mathrm{NPs}$ ); (b, f) groups treated with $200 \mathrm{mg} \mathrm{L}^{-1} \mathrm{TiO}_{2} \mathrm{NPs}$ for $24 \mathrm{~h}$; (c, g) $50 \mathrm{mg} \mathrm{L}^{-1} \mathrm{TiO}_{2} \mathrm{NPs}$ for $48 \mathrm{~h}$, and (d, h) $200 \mathrm{mg} \mathrm{L}^{-1} \mathrm{TiO}_{2} \mathrm{NPs}_{\text {for }} 48 \mathrm{~h}$. (i-p) Representative histological photomicrographs of the liver in young and adult rats after gastrointestinal exposure to $\mathrm{TiO}_{2} \mathrm{NPs}_{\text {for }} 30$ days. Circles: liver edema in young rats. Arrows: inflammatory cell infiltration in adult rat liver Y0-Y3: young rats, A0-A3: adult rats, Y0 \& A0: control group (0 mg $\left.\mathrm{kg}^{-1}\right)$, Y1 \& A1: low-dose exposure group (10 mg kg-1), Y2 \& A2: middle-dose exposure group (50 $\left.\mathrm{mg} \mathrm{kg}^{-1}\right), \mathrm{Y} 3$ \& A3: high-dose exposure group (200 $\mathrm{mg} \mathrm{kg}^{-1}$ ). Reprinted with permission from: (a-h) Ref. [31], Copyright 2015, Royal Society of Chemistry; (i-p) Ref. [49], Copyright 2013, WILEY-VCH Verlag GmbH \& Co. KGaA, Weinheim.

of $\mathrm{TiO}_{2} \mathrm{NPs}$ are energy-dependent. NPs enter into the cells via a receptor-mediated pathway. The endocytosis rate of $\mathrm{TiO}_{2} \mathrm{NPs}$ was highly dependent on size and shape, while the exocytosis ratio was largely dependent on the original concentration, endocytosis amount and shapes, but was less affected by size.

\section{In vivo studies}

Compared with in vitro studies, in vivo studies can provide data in abundance. Many researchers studied the in vivo toxicity of $\mathrm{TiO}_{2} \mathrm{NPs}$. $\mathrm{TiO}_{2} \mathrm{NPs}$ can enter into the human body via various routes [40], increasing their potential hazard to human health. The skin is the largest organ in our body that is exposed to nanomaterials. Lademann et al. [41] reported that $\mathrm{TiO}_{2} \mathrm{NPs}$ can pass through the human stratum corneum and reach the epidermis, and even the dermis. In addition, Wu et al. [42] showed that $\mathrm{TiO}_{2}$ NPs penetrate through the skin, and reach major organs in mice. Another possible entry route of $\mathrm{TiO}_{2} \mathrm{NPs}$ is via res- piratory tract. Many studies demonstrated that NPs reach the highly vascularized alveoli regions in deep lung $[43,44]$. Some studies reported the pulmonary toxicity of $\mathrm{TiO}_{2} \mathrm{NP}$ exposure in terms of increased bronchoalveolar lavage inflammatory parameters [45-47]. In addition, $\mathrm{TiO}_{2} \mathrm{NPs}$ enter into the human body through food directly. Chen et al. [48] studied $\mathrm{TiO}_{2} \mathrm{NPs}$ in sugar-coated gum. They showed that $\mathrm{TiO}_{2} \mathrm{NPs}$ passed through the gastrointestinal tract and distributed to other organs, resulting in their gradual accumulation in the whole body. Wang et al. [49] studied the oral toxicity of $\mathrm{TiO}_{2} \mathrm{NPs}$ in young and adult rats. Pathological and histological analysis revealed that treatment with high-dose $\mathrm{TiO}_{2} \mathrm{NPs}\left(200 \mathrm{mg} \mathrm{kg}^{-1}\right)$ induced liver edema, hepatic cord disarray, perilobular cell swelling, hydropic degeneration, or vacuolization in young rats. Inflammatory cell infiltration was observed in adult rat liver (10 and 50 $\mathrm{mg} \mathrm{kg}{ }^{-1} \mathrm{TiO}_{2}$ NP-treated groups; Fig. 1i-p). Biochemical parameters in the serum (Table 1) showed that decrease in total bilirubin (TBIL) and increase in blood urea nitrogen 
Table 1 Biochemistry assay of serum in rats after gastrointestinal exposure to $\mathrm{TiO}_{2} \mathrm{NPs}_{\text {for }} 30$ days (mean $\pm \mathrm{SD}, n=7$ ) [49]

\begin{tabular}{|c|c|c|c|c|c|c|c|c|c|c|}
\hline Group & $\begin{array}{l}\text { Exposure } \\
\text { dose }\end{array}$ & $\begin{array}{c}\text { Glu } \\
{\left[\mathrm{mmol} \mathrm{L}^{-1}\right]}\end{array}$ & $\begin{array}{c}\text { TCHO } \\
{\left[\mathrm{mmol} \mathrm{L}^{-1}\right]}\end{array}$ & $\begin{array}{c}\mathrm{TG} \\
{\left[\mathrm{mmol} \mathrm{L}^{-1}\right]}\end{array}$ & $\begin{array}{c}\text { HDL-C } \\
{\left[\mathrm{mmol} \mathrm{L}^{-1}\right]}\end{array}$ & $\begin{array}{c}\text { LDL-C } \\
{\left[\mathrm{mmol} \mathrm{L}^{-1}\right]}\end{array}$ & $\begin{array}{c}\mathrm{TP} \\
{\left[\mathrm{g} \mathrm{L}^{-1}\right]}\end{array}$ & $\begin{array}{c}\text { ALB } \\
{\left[\mathrm{g} \mathrm{L}^{-1}\right]}\end{array}$ & $\begin{array}{l}\mathrm{GLB} \\
{\left[\mathrm{g} \mathrm{L}^{-1}\right]}\end{array}$ & ALB/GLB \\
\hline \multicolumn{11}{|l|}{ Youth } \\
\hline Y0 & $0 \mathrm{mg} \mathrm{kg}^{-1} \mathrm{BW}$ & $5.04 \pm 0.98$ & $1.59 \pm 0.22$ & $0.82 \pm 0.29$ & $0.60 \pm 0.07$ & $0.23 \pm 0.03$ & $70.86 \pm 2.85$ & $36.51 \pm 1.29$ & $34.34 \pm 1.74$ & $1.06 \pm 0.04$ \\
\hline Y2 & $50 \mathrm{mg} \mathrm{kg}^{-1} \mathrm{BW}$ & $6.61 \pm 0.73^{* *}$ & $1.91 \pm 0.30$ & $0.59 \pm 0.13$ & $0.60 \pm 0.07$ & $0.43 \pm 0.09^{* *}$ & $1.57 \pm 1.62$ & $36.54 \pm 0.98$ & $35.03 \pm 1.38$ & $1.04 \pm 0.05$ \\
\hline Y3 & $200 \mathrm{mg} \mathrm{kg}^{-1} \mathrm{BW}$ & $6.44 \pm 0.36^{* *}$ & $1.69 \pm 0.36$ & $0.63 \pm 0.13$ & $0.58 \pm 0.08$ & $0.36 \pm 0.05^{* *}$ & $69.86 \pm 2.79$ & $35.99 \pm 1.27$ & $33.87 \pm 1.75$ & $1.06 \pm 0.04$ \\
\hline \multicolumn{11}{|l|}{ Adult } \\
\hline A0 & $0 \mathrm{mg} \mathrm{kg}^{-1} \mathrm{BW}$ & $5.73 \pm 1.57$ & $1.65 \pm 0.35$ & $0.84 \pm 0.30$ & $0.62 \pm 0.10$ & $0.26 \pm 0.06$ & $70.43 \pm 2.70$ & $35.66 \pm 1.35$ & $34.77 \pm 1.71$ & $1.03 \pm 0.04$ \\
\hline $\mathrm{A} 1$ & $10 \mathrm{mg} \mathrm{kg}^{-1} \mathrm{BW}$ & $5.13 \pm 1.09$ & $1.72 \pm 0.25$ & $0.72 \pm 0.20$ & $0.67 \pm 0.06$ & $0.27 \pm 0.06$ & $70.71 \pm 3.64$ & $35.34 \pm 1.67$ & $35.37 \pm 2.23$ & $1.00 \pm 0.04$ \\
\hline $\mathrm{A} 2$ & $50 \mathrm{mg} \mathrm{kg}^{-1} \mathrm{BW}$ & $4.88 \pm 0.88$ & $1.83 \pm 0.37$ & $0.52 \pm 0.11$ & $0.64 \pm 0.07$ & $0.29 \pm 0.05$ & $72.17 \pm 2.23$ & $35.67 \pm 1.03$ & $36.50 \pm 2.35$ & $0.98 \pm 0.08$ \\
\hline A3 & $200 \mathrm{mg} \mathrm{kg}^{-1} \mathrm{BW}$ & $5.06 \pm 0.36$ & $1.61 \pm 0.28$ & $0.82 \pm 0.37$ & $0.59 \pm 0.07$ & $0.24 \pm 0.05$ & $68.86 \pm 2.54$ & $34.54 \pm 1.58$ & $34.31 \pm 1.60$ & $1.01 \pm 0.06$ \\
\hline Group & $\begin{array}{l}\text { Exposure } \\
\text { dose }\end{array}$ & ALT $\left[\mathrm{U} \mathrm{L}^{-1}\right]$ & $\begin{array}{c}\mathrm{AST} \\
{\left[\mathrm{U} \mathrm{L}^{-1}\right]}\end{array}$ & ALT/AST & $\begin{array}{c}\text { TBIL } \\
{\left[\mu \mathrm{mol} \mathrm{L}^{-1}\right]}\end{array}$ & $\begin{array}{c}\mathrm{LDH} \\
{\left[\mathrm{U} \mathrm{L}^{-1}\right]}\end{array}$ & $\begin{array}{l}\mathrm{HBDH} \\
{\left[\mathrm{U} \mathrm{L}^{-1}\right]}\end{array}$ & $\begin{array}{c}\mathrm{CK} \\
{\left[\mathrm{U} \mathrm{L}^{-1}\right]}\end{array}$ & $\begin{array}{c}\text { BUN } \\
{\left[\mathrm{mmol} \mathrm{L}^{-1}\right]}\end{array}$ & $\begin{array}{c}\text { Crea } \\
{\left[\mu \mathrm{mol} \mathrm{L}^{-1}\right]}\end{array}$ \\
\hline \multicolumn{11}{|l|}{ Youth } \\
\hline Y0 & $0 \mathrm{mg} \mathrm{kg}^{-1} \mathrm{BW}$ & $47.57 \pm 4.83$ & $209.14 \pm 31.91$ & $0.23 \pm 0.04$ & $1.27 \pm 0.21$ & $1852.86 \pm 467.30$ & $890.43 \pm 344.28$ & $2792.00 \pm 294.97$ & $6.93 \pm 1.08$ & $52.57 \pm 5.32$ \\
\hline Y2 & $50 \mathrm{mg} \mathrm{kg}^{-1} \mathrm{BW}$ & $54.43 \pm 7.09$ & $152.14 \pm 28.20^{* *}$ & $0.37 \pm 0.07^{* *}$ & $1.47 \pm 0.18$ & $1313.86 \pm 346.95$ & $510.86 \pm 168.34^{* *}$ & $2154.43 \pm 914.55$ & $6.49 \pm 1.10$ & $52.86 \pm 3.07$ \\
\hline Y3 & $200 \mathrm{mg} \mathrm{kg}^{-1} \mathrm{BW}$ & $48.86 \pm 6.39$ & $157.57 \pm 31.83^{* *}$ & $0.32 \pm 0.06^{*}$ & $2.11 \pm 0.30^{* *}$ & $1499.43 \pm 383.68$ & $617.28 \pm 222.54^{*}$ & $1658.00 \pm 685.07^{*}$ & $6.44 \pm 1.11$ & $49.71 \pm 2.75$ \\
\hline \multicolumn{11}{|l|}{ Adult } \\
\hline A0 & $0 \mathrm{mg} \mathrm{kg}^{-1} \mathrm{BW}$ & $52.43 \pm 6.16$ & $170.43 \pm 38.31$ & $0.32 \pm 0.07$ & $1.81 \pm 0.13$ & $1548.86 \pm 393.39$ & $692.86 \pm 328.89$ & $2045.86 \pm 520.32$ & $5.60 \pm 0.91$ & $53.43 \pm 3.10$ \\
\hline $\mathrm{A} 1$ & $10 \mathrm{mg} \mathrm{kg}^{-1} \mathrm{BW}$ & $47.43 \pm 5.65$ & $178.57 \pm 54.36$ & $0.28 \pm 0.05$ & $2.09 \pm 0.41$ & $1753.71 \pm 545.80$ & $835.71 \pm 439.23$ & $2176.86 \pm 777.33$ & $6.43 \pm 0.94$ & $53.00 \pm 8.74$ \\
\hline A2 & $50 \mathrm{mg} \mathrm{kg}^{-1} \mathrm{BW}$ & $46.00 \pm 5.66$ & $167.83 \pm 31.24$ & $0.29 \pm 0.08$ & $1.90 \pm 0.29$ & $1560.33 \pm 336.45$ & $690.83 \pm 232.51$ & $1789.17 \pm 459.89$ & $8.42 \pm 1.96^{++}$ & $54.33 \pm 5.96$ \\
\hline A3 & $200 \mathrm{mg} \mathrm{kg}^{-1} \mathrm{BW}$ & $51.57 \pm 9.05$ & $177.00 \pm 19.21$ & $0.29 \pm 0.03$ & $1.37 \pm 0.50^{+}$ & $1647.29 \pm 44.32$ & $709.29 \pm 27.40$ & $2041.86 \pm 337.52$ & $7.26 \pm 0.61^{+}$ & $50.29 \pm 4.57$ \\
\hline
\end{tabular}

Significant difference from group Y0 $\left({ }^{*} p<0.05,{ }^{* *} p<0.01\right)$; significant difference from group A0 $\left({ }^{+} p<0.05,{ }^{+} p<0.01\right)$. 
(BUN) indicated slight injury in the liver and kidneys of adult rats treated at high doses ( 50 and $200 \mathrm{mg} \mathrm{kg}^{-1}$ ). However, young rats were more sensitive to high-dose exposure (50 and $200 \mathrm{mg} \mathrm{kg}^{-1}$ ) of $\mathrm{TiO}_{2} \mathrm{NPs}$, which indicate that $\mathrm{TiO}_{2}$ NPs can cause greater health hazard to young rats exposed to high doses. Some scientists further studied the toxicity and bio-distribution of $\mathrm{TiO}_{2} \mathrm{NPs}$ in long-term and lowdose exposure to evaluate the toxicity of $\mathrm{TiO}_{2} \mathrm{NPs}$. Fang et al. [50] examined the long-term (1, 3, and 4 months) subchronic toxicity and bio-distribution of $\mathrm{TiO}_{2} \mathrm{NPs}$ with various sizes ( 25 and $80 \mathrm{~nm}$ ). They reported that both sizes of $\mathrm{TiO}_{2} \mathrm{NPs}$ were mainly accumulated in the spleen and liver, and $80 \mathrm{~nm} \mathrm{TiO}{ }_{2}$ NPs were also found in the lungs. It is difficult to clear $\mathrm{TiO}_{2} \mathrm{NPs}$ from the body, and many $\mathrm{TiO}_{2} \mathrm{NPs}$ were observed in the spleen and liver even after 4 months. No subchronic toxicity was observed, while varying degrees of lesions appeared in the spleen, liver, and lung. Furthermore, they also studied the long term effects of exposure routes on bio-distribution and toxicity [51]. They revealed that the bio-distribution of $\mathrm{TiO}_{2} \mathrm{NPs}$ depended on the exposure route, time, and size.

In brief, $\mathrm{TiO}_{2} \mathrm{NPs}$ have a relatively low toxicity, but exposure to high doses can cause damage to the cells and tissues. $\mathrm{TiO}_{2} \mathrm{NPs}$ enter the body, accumulate in various organs, and show a very slow metabolism rate. High-dose and long-time exposure of $\mathrm{TiO}_{2} \mathrm{NPs}$ would affect the function of major organs such as the liver and kidney. The safe dosage of $\mathrm{TiO}_{2} \mathrm{NPs}$ in commercial products should be noted, and it may be necessary to pay attention to the age of the user as $\mathrm{TiO}_{2} \mathrm{NPs}$ show more damage in youth.

\section{Zinc oxide nanoparticles}

$\mathrm{ZnO}$ NPs have been widely applied because of their unique physicochemical properties [52-54]. They are traditionally used in sunscreens owing to their ability to filter UV rays strongly [55]. In addition, they are an attractive candidate for sensors because of their excellent electrochemical activity [56,57]. Moreover, zinc is an important essential trace element in human beings. Therefore, $\mathrm{ZnO}$ NPs are widely used as food additives and nutritional supplements $[56,57]$. Hence, it is necessary to study the related bio-toxicity of $\mathrm{ZnO}$ NPs.

\section{In vitro studies}

The results of the present study suggested that $\mathrm{ZnO}$ NPs had higher toxicity compared with other MONPs. According to the results of cell counting kit- 8 assay performed by Wang et al. [31,58], after exposure of GES-1 (human gastric epithelial) cells to $25 \mathrm{mg} \mathrm{L}^{-1} \mathrm{ZnO} N P s$ for $24 \mathrm{~h}$, the rate of cell death was as high as $80 \%$. However, cell viability was above $80 \%$ after exposure to $200 \mathrm{mg} \mathrm{L}^{-1} \mathrm{TiO}_{2} \mathrm{NPs}$. Other reports demonstrated that $\mathrm{ZnO}$ NPs were toxic to a number of types of cells, such as Tetrahymena thermophila [59], osteoblastic MC3T3-E1 cells [60], and A549 (human lung cancer) cell line [61]. Chen et al. [62] investigated the cellular response induced by $\mathrm{ZnO}$ NPs in human umbilical vein endothelial cells (HUVECs). They found that $240 \mu \mathrm{mol} \mathrm{L}^{-1}$ $\mathrm{ZnO}$ NPs induced relatively higher levels of ROS in HUVECs compared with $\mathrm{CeO}_{2} \mathrm{NPs}$ treated at the same dosage after $8 \mathrm{~h}$ of incubation. Quantitative analysis showed that the ROS level of $\mathrm{ZnO}$ NPs-treated group increased significantly at doses higher than $120 \mu \mathrm{mol} \mathrm{L}^{-1}$ (Fig. 2). ZnO NPs can induce loss of cell viability, increase in ROS, DNA damage, and apoptosis [63]. The physical properties (size and shape) of ZnO NPs would have an impact on their toxicity. It has been observed that ZnO NPs (approximately 100 $\mathrm{nm}$ ) had higher bio-toxicity than bulk ZnO (approximately $5 \mu \mathrm{m}$ ) [64]. Rod shaped ZnO NPs induced greater toxicity than spherical ZnO NPs. Different sizes and shapes would affect the interaction between ZnO NPs and cells exhibiting the size- and shape-dependent toxicities of ZnO NPs. In addition, the release rates of $\mathrm{Zn}^{2+}$ ions are different for different $\mathrm{ZnO}$ NPs [65].

\section{In vivo studies}

Since $\mathrm{ZnO}$ NPs are often used in cosmetics, its toxicity on the human skin is worthy of attention. The potential toxicity of $\mathrm{ZnO}$ NPs present in sunscreens is due to their small size as well as their ability to escape immunologic defense mechanisms, form complexes with proteins, and induce ROS formation [66]. Toxicity of $\mathrm{ZnO}$ NPs can occur at two different levels: first, at the skin barrier constituted by cells; second, after reaching the tissues from systemic circulation. The ability of $\mathrm{ZnO}$ NPs to penetrate the skin barrier was studied by many scientists. Cross et al. [67] reported the dermal absorption of ZnO NPs. When Franz-type diffusion cells were exposed to a sunscreen formulation containing ZnO NPs for $24 \mathrm{~h}$, no ZnO NPs penetration was observed. Moreover, electron microscopy results indicated that no NPs were detected in the lower stratum corneum or viable epidermis. Filipe et al. [68] studied the penetration of ZnO NPs into normal and psoriatic human skin in vivo. They revealed that when the human skin was exposed to three marketed sunscreens containing ZnO NPs for 2 $h$, these NPs were only detectable in the stratum corneum. There were no ZnO NPs in the deeper skin layers, even after $48 \mathrm{~h}$ exposure to the sunscreens, under occlusion. To date, there is no evidence that $\mathrm{ZnO}$ NPs can penetrate the skin barrier to enter the cell or deeper tissues. However, some 


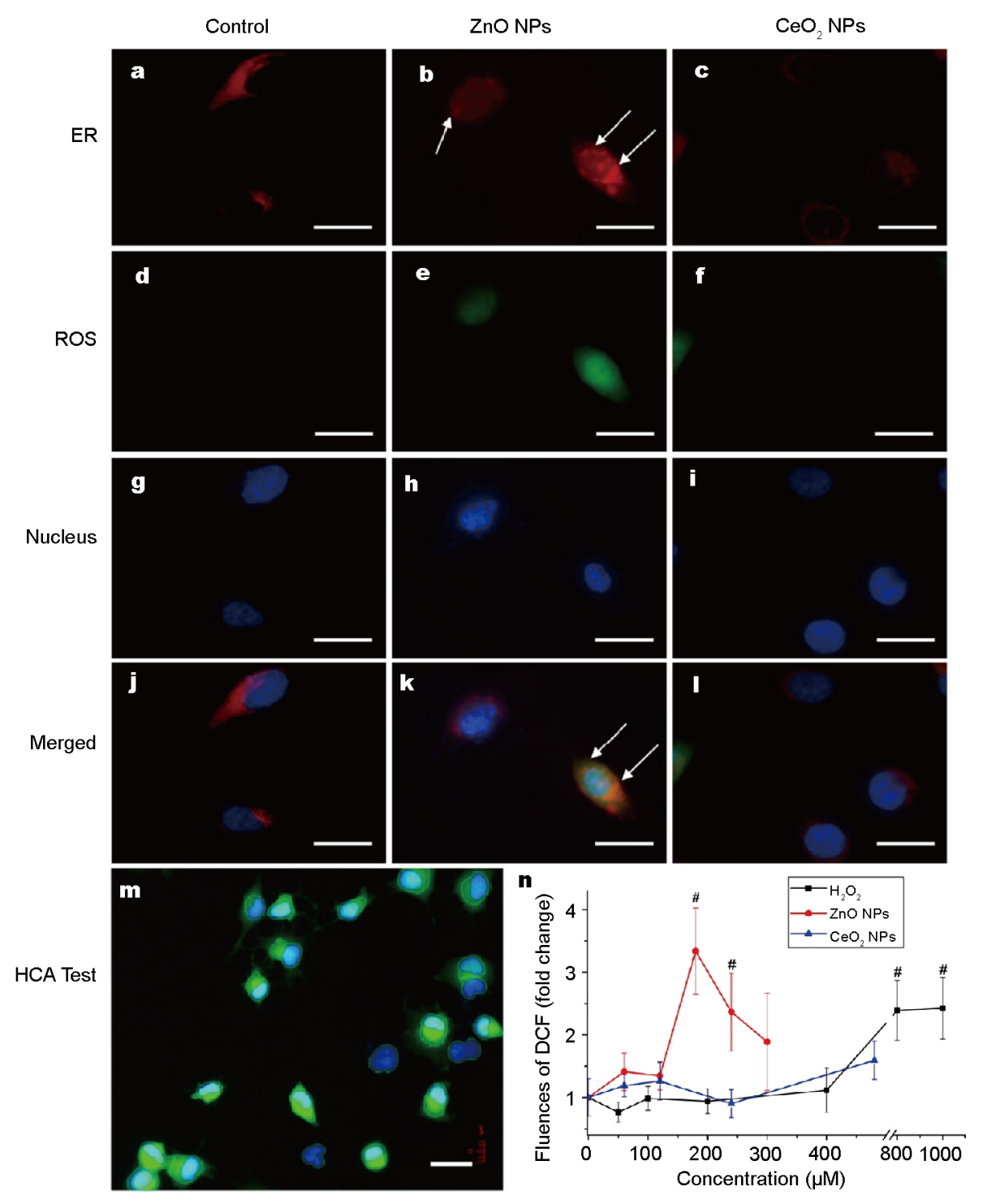

Figure 2 ROS levels in HUVECs after exposure to NPs. (a-l) Fluorescence microscope images of intracellular ROS induced by NPs. HUVECs were treated with $\mathrm{ZnO} N \mathrm{Ns} / \mathrm{CeO}_{2} \mathrm{NPs}\left(240 \mu \mathrm{mol} \mathrm{L}^{-1}\right)$ for $8 \mathrm{~h}$; then the endoplasmatic reticulum (ER) and ROS were stained. (m) Image from ZnO NPs-treatment group shows the segmentation process of high-content analysis (HCA) method. (n) Quantitative analyses of ROS levels by HCA after HUVECs were treated with NPs for $8 \mathrm{~h}$. Data is expressed as mean $\pm \mathrm{SD}$, (\# $p<0.01$ compared with that in blank, $n=6$. Bars: $10 \mu \mathrm{m})$. The white arrows show bright and aggregated ER in ZnO NPs-treated cells. Reprinted with permission from Ref. [62], Copyright 2014, American Chemical Society.

researchers reported the phototoxicity of bulk and $\mathrm{ZnO}$ NPs in Caenorhabditis elegans nematode [66]. Phototoxicity is an irritation reaction to sunlight caused by chemical substances in the skin. All the results of previous studies showed that the phototoxicity of ZnO NPs was significantly enhanced under natural sunlight, and they were more likely to induce phototoxicity than bulk $\mathrm{ZnO}$ particles. Jang et al. [69] observed the phototoxicity of ZnO NPs at the tested concentrations with the 3T3 (mouse fibroblast cell) neutral red uptake test. The mechanism of phototoxicity involves the absorption of photons with energy similar to the band gap energy by the $\mathrm{ZnO}$ NPs as well as the generation of hole/electron pairs and consequently ROS, which can cause damage to the cells and organs [54].

$\mathrm{ZnO}$ NPs are also widely applied in food additives. They have been used as a dietary supplement in humans and animals because zinc can stimulate the immune system and exert anti-inflammatory effects $[70,71]$. Therefore, oral toxicity has attracted much attention recently. Sharma et al. [72] reported that significant accumulation of NPs in the liver following sub-acute oral exposure of ZnO NPs (300 $\mathrm{mg} \mathrm{kg}^{-1}$ ) for 14 consecutive days leads to cellular injury. 
These results were supported by the findings of Ko et al. [73]. They reported sub-acute oral dose toxicity of $100 \mathrm{~nm}$ $\mathrm{ZnO}$ NPs administered to rats by gavage at $0,500,1,000$, and 2,000 $\mathrm{mg} \mathrm{kg}^{-1}$ day $^{-1}$ for 14 days. Their results showed significant changes in clinical signs, body weight, hematology, histopathology, and serum biochemistry at doses higher than $500 \mathrm{mg} \mathrm{kg}^{-1} \mathrm{day}^{-1}$.

In summary, $\mathrm{ZnO} \mathrm{NPs}$ cannot penetrate the skin barrier easily and enter the organisms; however, their phototoxicity has been confirmed. They can enter the organism by direct oral exposure leading to tissue injury.

\section{Iron oxide nanoparticles}

Owing to excellent biocompatibility, IONPs have been frequently used in biomedical fields [74-76]. The term IONPs include both superparamagnetic iron oxide nanoparticles (SPION) and magnetic IONPs, among which hematite $\left(\alpha-\mathrm{Fe}_{2} \mathrm{O}_{3}\right)$, maghemite $\left(\gamma-\mathrm{Fe}_{2} \mathrm{O}_{3}\right)$, and magnetite $\left(\mathrm{Fe}_{3} \mathrm{O}_{4}\right)$ are the most common. Maghemite $\left(\gamma-\mathrm{Fe}_{2} \mathrm{O}_{3}\right)$ and magnetite $\left(\mathrm{Fe}_{3} \mathrm{O}_{4}\right)$ are by far the most commonly employed magnetic nanoparticles for biomedical applications. IONPs are well developed and designed to be used in biosensors, magnetic resonance imaging (MRI), labeling and sorting of cells, tissue-specific release of therapeutic agents, and separation of biochemical products [77,78]. Exploring the toxicology of IONPs is the foundation for their safe and wide application.

\section{In vitro studies}

IONPs possess great biocompatibility and are similar to endogenous iron. Hence, they were considered non-toxic in the beginning. However, with the development of synthesis technology, various nanostructures of IONPs were synthesized and widely applied. The toxicity of IONPs is determined by different factors such as shapes, sizes, coating layers, and functional groups. Many studies have already shown that IONPs induce cytotoxicity. Cai et al. [79] reported that polyethylenimine (PEI)-coated IONPs were more toxic than polyethylene glycol (PEG)-coated IONPs owing to the strong electrostatic interaction between the negatively charged cell surface and positively charged IONPs, though PEI might be a disturbing factor in this case. Berry et al. [80] observed that uncoated/dextran-coated $\mathrm{Fe}_{3} \mathrm{O}_{4}$ NPs induced vacuole formation and disrupted the clearance function of the skeleton of dermal fibroblasts, and they were able to cause varying degrees of cell death. Similarly, Stroh et al. [81] confirmed that a huge amount of citrate-coated $\gamma-\mathrm{Fe}_{2} \mathrm{O}_{3} \mathrm{NPs}$ in cells resulted in a significant increase of protein oxidation and ROS level. The toxicities of IONPs with different surface coatings in vitro are shown in Table 2. The results indicated that the toxicity was also size-, shape-, dose-, and time-dependent [82-89]. Many studies presently performed on toxicity evaluation are far away from reaching a conclusion and providing guidance for the safe application of IONPs. Therefore, we should consider a more comprehensive cytotoxicity evaluation for the synthesis and utilization of these NPs.

\section{In vivo studies}

Many reports indicate that IONPs can easily accumulate in the tissues by various exposure routes. IONPs administered via intravenous route were found to accumulate in the liver, spleen, testis, lung, and brain [90]. Gu et al. [91] found that excess iron accumulated in the indicated organs $24 \mathrm{~h}$ after intravenous injection $\left(5 \mathrm{mg} \mathrm{Fe} \mathrm{kg}^{-1}\right)$ of PEG-phospholipid-coated IO nanocrystals. And a large quantity of iron-containing degradation products from the IONPs was stored in the spleen after intravenous injection (5 $\mathrm{mg} \mathrm{Fe} \mathrm{kg}^{-1}$ ) (Fig. 3). Zhu et al. [92] intratracheally (i.t.)

Table 2 Toxicities of IONPs with different surface coatings in vitro

\begin{tabular}{|c|c|c|c|c|c|}
\hline Coating material & Cell types & Size $(\mathrm{nm})$ & Concentration & Incubation time & Result \\
\hline \multirow[t]{2}{*}{ Dextran } & Macrophages (human) & $100-150$ & $0.1 \mathrm{mg} \mathrm{mL}^{-1}$ & 7 days & $20 \%$ cell viability after 7 days $[82]$ \\
\hline & $\begin{array}{l}\text { Primary peritoneal macrophages } \\
\text { (rats and mice) }\end{array}$ & 20,60 & $0.2-20 \mu \mathrm{mol} \mathrm{L}^{-1}$ & 15 min-2 days & $\begin{array}{l}\text { Increased anti-inflammatory cytokines, } \\
\text { reduced pro-inflammatory cytokines }[83]\end{array}$ \\
\hline Poly (vinyl alcohol) & L929 (mouse fibroblasts) & 82 & $0.2-20 \mathrm{mmol} \mathrm{L}^{-1}$ & 2 days & $\begin{array}{l}\text { Toxicity depends on nanoparticles shape and } \\
\text { size [84] }\end{array}$ \\
\hline Amine-surface & HepG2 (human liver cancer cell) & $61-127$ & $0.03-3000 \mu \mathrm{g} \mathrm{mL}^{-1}$ & 5 days & $\begin{array}{l}\text { High positive charge causes severe } \\
\text { cytotoxicity [85] }\end{array}$ \\
\hline Tween & macrophages J774 (mouse) & 30 & $25-500 \mu \mathrm{g} \mathrm{mL}^{-1}$ & $1-6 \mathrm{~h}$ & Dose- and time-dependent damage [86] \\
\hline Silica & A549 (human lung cancer cell) & $30-120$ & $10 \mu \mathrm{g} \mathrm{mL} L^{-1}$ & 2 days & Dose- and size-dependent damage [87] \\
\hline Uncoated & A549 (human lung cancer cell) & $20-30$ & Up to $80 \mu \mathrm{g} \mathrm{mL}^{-1}$ & $18 \mathrm{~h}$ & No or low toxicity [88] \\
\hline Uncoated & BRL 3A (rat liver derived cell) & 30,47 & Up to $250 \mu \mathrm{g} \mathrm{mL}^{-1}$ & 1 days & $\begin{array}{l}\text { No toxicity up to } 100 \mu \mathrm{g} \mathrm{mL}^{-1} \text {, significant } \\
\text { toxic effects at } 250 \mu \mathrm{gL}^{-1}[89]\end{array}$ \\
\hline
\end{tabular}



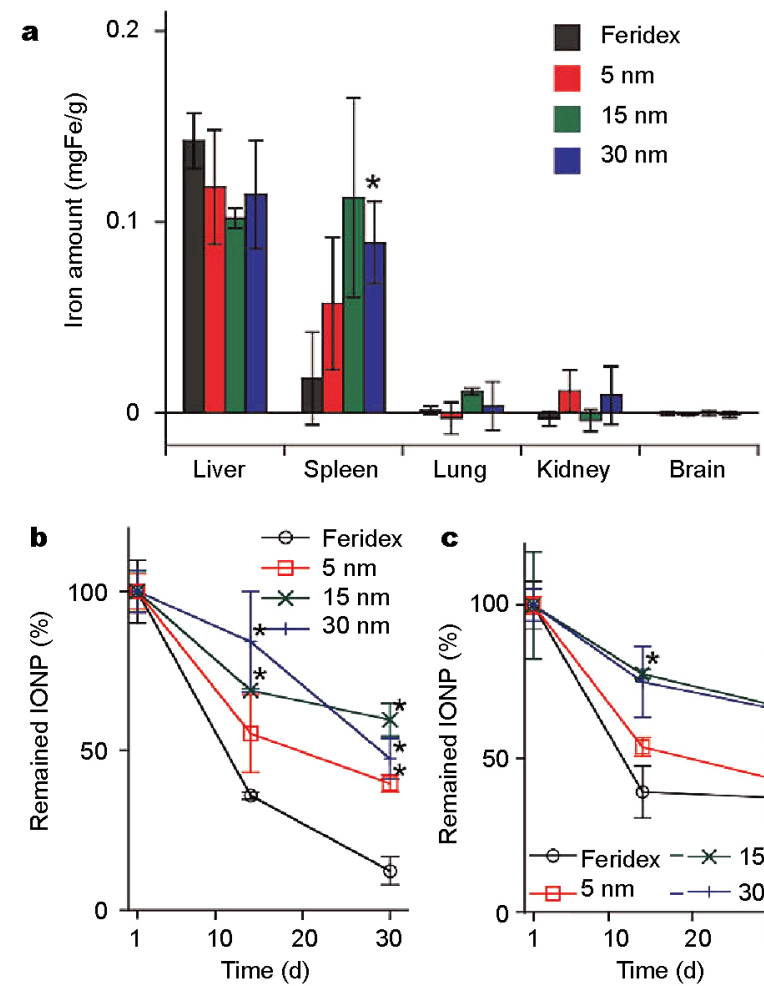

Figure 3 In vivo accumulation, degradation, and clearance of IONPs in mice. (a) Iron distributed in the liver, spleen, lung, kidney and brain after intravenous injection ( $5 \mathrm{mg} \mathrm{Fe} \mathrm{kg}{ }^{-1}$ ) of PEG-phospholipid-coated IO nanocrystals for $24 \mathrm{~h}$, prepared via the organometallic route (sizes of $\sim 5$, $\sim 15$, and $\sim 30 \mathrm{~nm}$ ), and Feridex (is a dextran-coated cluster of IONPs approved as a contrast agent for hepatic imaging). (b, c) Percent of IONPs (percent superparamagnetic/ferrimagnetic content) remaining in liver (b) and spleen (c). Reprinted with permission from Ref. [91], Copyright 2012, American Chemical Society.

instilled $22 \mathrm{~nm}^{59} \mathrm{Fe}_{2} \mathrm{O}_{3} \mathrm{NPs}$ (4 mg/rat) into rats. They found that ${ }^{59} \mathrm{Fe}_{2} \mathrm{O}_{3}$ NPs can pass through the alveolar-capillary barrier and enter into the systemic circulation in $10 \mathrm{~min}$. ${ }^{59} \mathrm{Fe}_{2} \mathrm{O}_{3} \mathrm{NPs}$ were taken up by the lung tissues and further distributed to the liver, spleen, and kidneys. Bellusci et al. [93] also found presence of iron in the liver, spleen, lung, and brain after inhalation of IONPs. The highest iron concentrations were observed in the liver and spleen. Small IONPs $(<10 \mathrm{~nm})$ can be rapidly removed through extravasation and renal clearance, while large IONPs (>200 nm) were sequestered by the spleen via mechanical filtration [94].

Various physicochemical factors of IONPs, such as surface chemistry, size, shape, and charge, also play a very crucial role in the toxicity of IONPs in animal studies $[95,96]$. Zhu et al. [97] confirmed that $\mathrm{Fe}_{2} \mathrm{O}_{3} \mathrm{NP}$ exposure can induce increased ROS level in the lungs after i.t. instillation of two sizes of $\mathrm{Fe}_{2} \mathrm{O}_{3}$ particles $(22$ and $280 \mathrm{~nm})$. In vivo studies have shown improved penetration of positively charged IONPs through the placenta compared with negatively charged IONPs in CD-1 mice [98]. Additionally, the tissue or cell type is another important factor that influences the toxicity response of IONPs. Hanini et al. [99] showed that IONPs can induce toxicity in the liver, kidney, and lung in vivo, while the brain and heart remained unaffected. In conclusion, the toxicity of IONPs is related to their physicochemical properties, such as surface chemistry, size, and shape. Further study needs to be performed on their biological toxicity.

\section{Other MONPs}

Some studies focused on other MONPs, such as $\mathrm{CuO}$, $\mathrm{Al}_{2} \mathrm{O}_{3}, \mathrm{CoO}$, and NiO NPs [100-103]. Sun et al. [100] reported that $\mathrm{CuO}$ NPs cause significant apoptosis of A549, H1650, and CNE-2Z cell lines. Furthermore, they pointed out that the cytotoxicity of $\mathrm{CuO}$ NPs may involve the autophagic pathway. Dong et al. [101] studied the toxicity of $\mathrm{Al}_{2} \mathrm{O}_{3}$ NPs. Their results showed that the toxicity of $\mathrm{Al}_{2} \mathrm{O}_{3}$ NPs was considerably low, although these particles are easily internalized into the cells. However, $\mathrm{CoO}$ and $\mathrm{NiO}$ NPs induce significant cytotoxicity [102].

\section{MECHANISM STUDY}

From the above, we can see that different MONPs have different toxicities. The mechanism underlying of the toxicity is still controversial. However, scientists have summarized some general principles for the toxicity of NPs based on results of all researches performed as follows: (i) toxicity of larger NPs is less than the smaller ones; (ii) in eukaryotes, NPs can cross and damage the biomembranes; (iii) oxidative stress is often caused by NPs; (iv) chemical compositions of NPs are closely connected to their toxicity; and (v) in prokaryotes, NPs often remain outside the cells, while in eukaryotes, they can enter into the cells or even the organisms $[104,105]$. At present, the toxicity mechanism is mainly divided into ROS-mediated apoptosis and non-ROS-related toxicity.

\section{ROS-mediated toxicity}

\section{Cellular mechanisms}

As is already known, increased levels of ROS, including free radicals such as the superoxide anion, hydroxyl radicals, and non-radical hydrogen peroxide, activate oxidative stress, which results in lipid peroxidation and cell membrane damage. Subsequently, the normal cell functions are lost leading to cell death or apoptosis $[102,106]$. ROS- 
mediated cytotoxicity is one of the most recognized toxicity mechanisms of MONPs $[13,107,108]$. There are several factors that induce the production of ROS by MONPs: (i) prooxidant functional groups on the reactive surface of NPs; (ii) active redox cycling on the surface of NPs; and (iii) NPs-cell interactions $[13,109]$.

Many studies have confirmed that ROS is generated on exposure to MONPs, including $\mathrm{ZnO}, \mathrm{TiO}_{2}, \mathrm{Fe}_{3} \mathrm{O}_{4}$, and $\mathrm{Fe}_{2} \mathrm{O}_{3}$ NPs [110-113]. Xiong et al. [110] detected that $\mathrm{TiO}_{2}$ and $\mathrm{ZnO}$ NP suspensions were able to generate $\cdot \mathrm{OH}$. Keratinocyte $\mathrm{HaCaT}$ cells exposed to $30 \mathrm{mg} \mathrm{mL}^{-1} \mathrm{TiO}_{2}$ NPs for $24 \mathrm{~h}$, showed $150 \%-200 \%$ increase in intracellular ROS compared with the untreated control [112]. The treatment of HepG2 (human hepatocarcinoma) cells with $20 \mathrm{mg} \mathrm{mL}^{-1} \mathrm{ZnO}$ NPs for $6 \mathrm{~h}$ induced a $200 \%$ increase in ROS levels [113]. High ROS levels can damage the cells by peroxidizing lipids, resulting in decline of physiological function and cell apoptosis or death. The cell membrane includes a lipid bilayer, and lipids are the primary target of ROS attack $[88,114]$. The deterioration of cell membrane causes extensive damage, which ultimately leads to cell death. Karlsson et al. [88] revealed that extensive lipid peroxidation was detected when A549 cells were exposed to $\mathrm{TiO}_{2}, \mathrm{ZnO}, \mathrm{Fe}_{3} \mathrm{O}_{4}$, and $\mathrm{Fe}_{2} \mathrm{O}_{3} \mathrm{NPs}$. The cellular amount of malondialdehyde (MDA) and release of LDH from the cells reflected lipid peroxidation and membrane damage increased. As iron $(\mathrm{Fe})$ and copper $(\mathrm{Cu})$ are transition metals, IONPs and $\mathrm{CuO}$ NPs can generate oxidative stress via Fenton-type reactions [111]. Therefore, the release of $\mathrm{Cu}$ - and $\mathrm{Fe}$-ion from the surface by enzymatic degradation is another reason for ROS generation.

\section{Molecular mechanisms}

Many studies have demonstrated that ROS can cause DNA damage. Damaged DNA elicits the activation of an important transcription factor, p53 [115]. When activated, p53 would upregulate the expression of Bax. In addition, p53 downregulates the expression of Bcl-2, an anti-apoptotic protein, which competes with Bax protein, leading to a decrease in the amount of heterodimer Bcl-2 to inhibit Bax function [116-118]. Bax, in turn forms a homodimer complex and induces pore formation in the lipid bilayer of mitochondrial membrane [119], and subsequently the apoptotic pathway is triggered. Song et al. [120] studied the oxidative DNA damage induced by MONPs in mice. Their results showed that DNA damage in the liver is dramatically enhanced. Li et al. [114] observed the suppression of Bcl-2 protein and genes followed by cytochrome $c$ release, increasing caspase- 3 and -9 in the spleen of $\mathrm{TiO}_{2}$ NPs-treated mouse.

In addition, high ROS levels would alter the permeabilization of mitochondrial membrane. Consequently, cytochrome c, a pro-apoptotic protein is released, and it then binds to procaspase- 9 to activate caspase- 9 . The activation of caspase- 9 in turn stimulates the release of caspase-3, which mediates the cell death process [121,122]. Manke et al. [123] reported cell apoptosis due to cerium oxide $\left(\mathrm{CeO}_{2}\right) \mathrm{NP}$ exposure, and they observed a distinct increase in ROS levels followed by decrease in mitochondrial membrane potential and release of caspase- 9 and -3 .

\section{Non-ROS-mediated toxicity}

Besides the mechanism of ROS-induced cytotoxicity, some researchers found that the excessive accumulation of low-toxicity materials such as $\mathrm{TiO}_{2} \mathrm{NPs}$ on the cell membrane is another important reason for cytotoxicity. [31,124-126]. Recently, Wang et al. [31] reported that excess $\mathrm{TiO}_{2}$ NPs on the cell surface is the major trigger for cytotoxicity. They demonstrated that the excess NPs attached on the cell membrane block the ion pathway, influence ion exchange, disrupt the exocytosis process, and finally lead to cell death. IONPs are magnetically targeted to a tissue/organ, and the high concentration of IONPs on the surface of the tissue/organ could induce toxicity [126].

In addition, the ions released from MONPs are related to cytotoxicity $[126,127]$. Many studies have confirmed that dissolved zinc ions of $\mathrm{ZnO}$ NPs significantly increased bio-toxicity. Excess $\mathrm{Zn}^{2+}$ can lead to an imbalance in homeostasis causing damage to the lysosomes and mitochondria, which in turn leads to cell death $[59,128,129]$. Some nanomaterials are intended for therapeutic purpose such as drug delivery. These nanomaterials are always designed to bind to specific receptors on the cell membrane. Binding of these nanomaterials to death receptors might lead to cell death by inducing a signal complex, which cleaves caspase-3 and activates caspase-8. Subsequently, cellular content degradation is initiated [130]. Zhao et al. [131] reported that $\mathrm{TiO}_{2}$ NPs can activate caspase-8 in JB6 mouse epidermal cells. Cui et al. [132] observed an increase of Toll-like receptors (TLR2 and TLR4) in mouse after $\mathrm{TiO}_{2} \mathrm{NP}$ exposure. The activation and increase of these receptors can induce inflammatory response and cell apoptosis. We summarize the bio-toxicity of MONPs in vitro and in vivo and their toxicity mechanism in Fig. 4.

\section{COMBINED TOXICITY EVALUATION OF MONPs}

Owing to the extensive use of MONPs in industrial and 


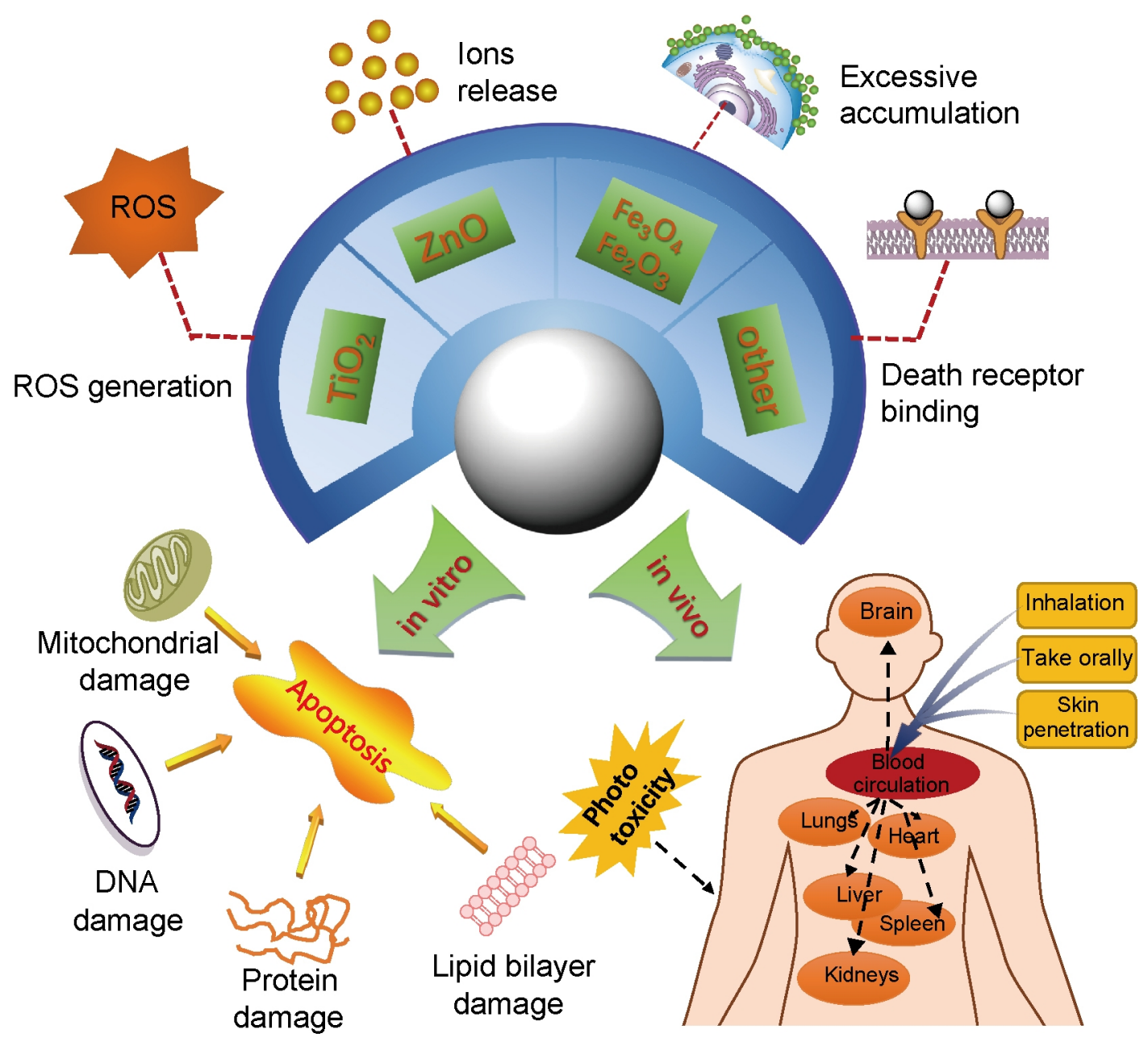

Figure 4. Schematic diagram of MONP toxicity and mechanism. In vitro toxicity of MONPs is mainly caused by the damage of mitochondrial/DNA/protein and phospholipid bilayer, leading to cell toxicity. In vivo toxicity is caused by penetration of MONPs into the blood circulation through inhalation, oral, and dermal routes, and these MONPs finally reach the main organs of the body causing organ damage. Some nanomaterials also cause phototoxicity on the skin. MONP toxicity is induced mainly by four ways: the generation of ROS, effect of released ions, excessive accumulation of NPs on the cell surface, and combination of NPs with specific death receptors.

consumer products, a variety of NPs are released into the environment. They are always in the form of a mixture. Previous studies performed to understand the behavior and risks of NPs are mostly limited to single NPs. However, these NPs may undergo complex physical and chemical transformations, like dissolution, complexation, adsorption, dispersion, and aggregation, influencing their respective fate and toxicity potential when used in industrial and consumer products. Therefore, studies on the fate and toxicology change of NPs in combined systems are attracting increasing attention of scientists worldwide.

\section{Combined toxicity between $\mathrm{TiO}_{2}$ and $\mathrm{ZnO}$ NPs}

$\mathrm{TiO}_{2}$ and $\mathrm{ZnO}$ NPs, two semiconductor MONPs, are among the most extensively used MONPs in industry.
The annual production volume and the predicted environmental concentrations of $\mathrm{TiO}_{2}$ and $\mathrm{ZnO}$ NPs are significantly higher than those of other frequently studied MONPs. Coupled with their wide and similar applications in personal-care products and industry, the interactions between these two NPs are worth investigating. Tong et al. [133] studied the chemical interactions between $\mathrm{TiO}_{2}$ and $\mathrm{ZnO}$ NPs in water matrix. Their results demonstrated that the presence of $\mathrm{TiO}_{2} \mathrm{NPs}$ influenced the dissolved zinc released from $\mathrm{ZnO}$ NPs in the solution. In the presence of $\mathrm{TiO}_{2} \mathrm{NPs}, \mathrm{Zn}$ (II)- $\mathrm{TiO}_{2}$ surface complexes are formed, which decrease the level of the free $\mathrm{Zn}$ ions in the solution, thereby reducing the toxicity of $\mathrm{ZnO} N$ Ps. The toxicity of soluble $\mathrm{ZnO}$ NPs and chemically stable $\mathrm{TiO}_{2} \mathrm{NPs}$ in combination was analyzed by monitoring the bacterial cell 

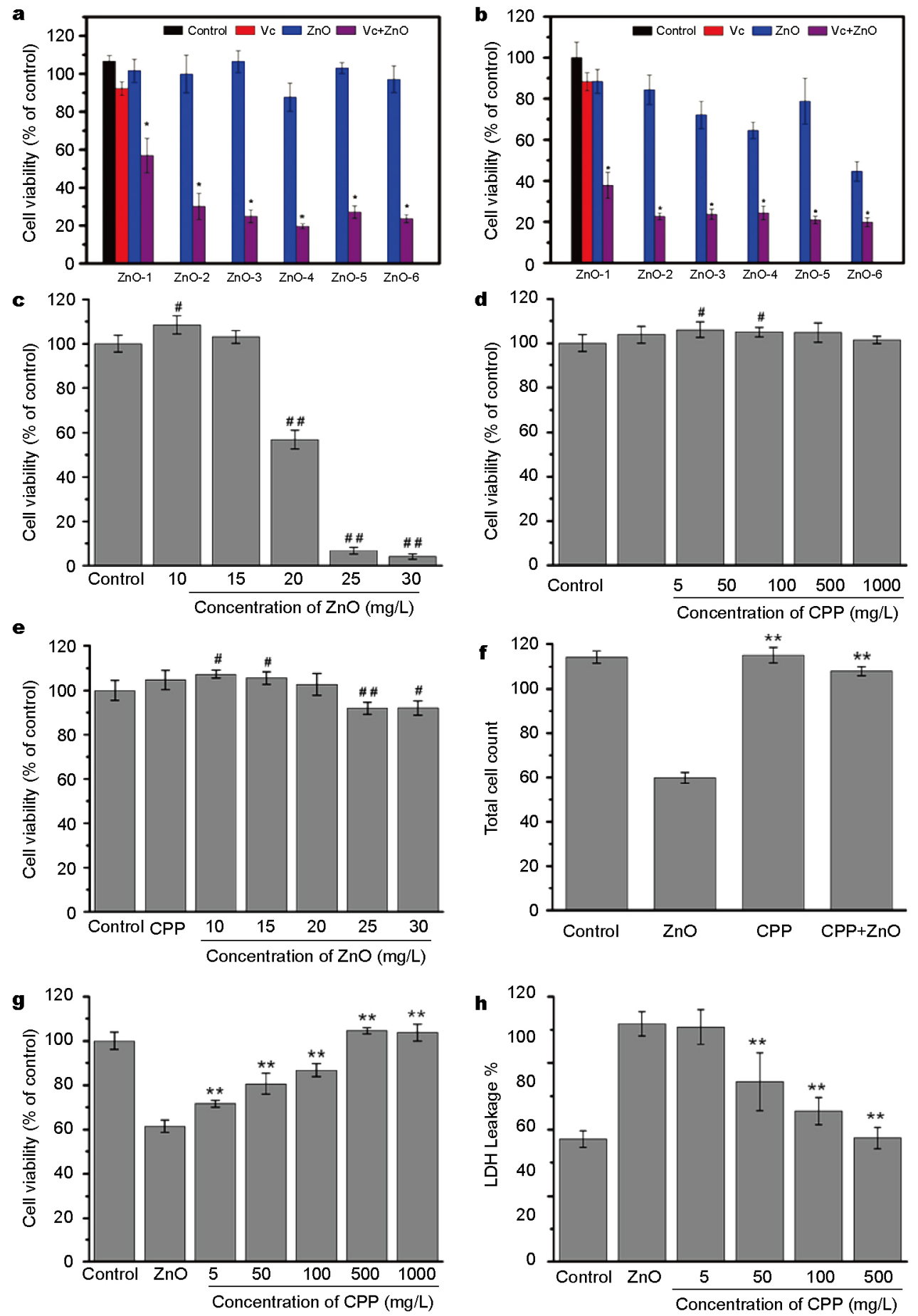

Figure 5 Cytotoxicity evaluation of ZnO NPs $\left(15 \mathrm{mg} \mathrm{L}^{-1}\right), \mathrm{Vc}\left(300 \mathrm{mg} \mathrm{L}^{-1}\right)$, and $\mathrm{ZnO} \mathrm{NPs}$ plus Vc treatment for $24 \mathrm{~h}(\mathrm{a}, \mathrm{b})$. Cell viability of gastric epithelial cell line (GES-1) (a), and neural stem cell line (NSCs) (b) after $24 \mathrm{~h}$ co-incubation with ZnO NPs, Vc, and ZnO NPs plus Vc treatment. ${ }^{*} p<$ 0.05 compared with cells exposed to $\mathrm{ZnO} N$ Ps. Cell viability after treatment of various concentrations of $\mathrm{ZnO} \mathrm{NPs}$ (c), various concentrations of CPP

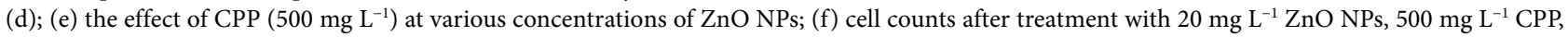
$20 \mathrm{mg} \mathrm{L}^{-1} \mathrm{ZnO}$ NPs \& $500 \mathrm{mg} \mathrm{L}^{-1} \mathrm{CPP}$, respectively; (g) the effects of various concentrations of CPP and ZnO NPs (20 mg L $\left.{ }^{-1}\right)$; (h) the effects on LDH release at various concentrations of CPP with ZnO NPs $\left(20 \mathrm{mg} \mathrm{L}^{-1}\right)$. $\# p<0.05$ compared with control group; ${ }^{*} p<0.05$ compared with cells exposed to ZnO NPs. Reprinted with permission from: (a, b) Ref. [58], Copyright 2014, Royal Society of Chemistry; (c-h) Ref. [135], Copyright 2014, Royal Society of Chemistry. 
membrane integrity and adenosine triphosphate (ATP) levels. Results show that there is reduced contact between $\mathrm{TiO}_{2} \mathrm{NPs}$ and bacteria in the presence of both $\mathrm{ZnO}$ NPs and dissolved zinc. However, this inhibitory effect of $\mathrm{ZnO} N P s$ on the adsorption of $\mathrm{Zn}^{2+}$ is reduced by $\mathrm{TiO}_{2} \mathrm{NPs}$ [134]; these provide the first evidence that interactions between multiple MONPs alter the toxicity of the individual NPs in unexpected ways. Therefore, we should pay particular attention to the combined toxicity of MONPs.

\section{Combined toxicity of MONPs in food additives}

Currently, the safety evaluation standards for MONPs as food additives are only based on the toxic effects of a single additive. However, when MONPs are used in a complex system with other food additives, toxicity may be dramatically influenced owing to various combined effects. However, only a few reports focus on the combined toxicity. Wang et al. [58] reported a combined toxicity study of $\mathrm{ZnO}$ NPs and vitamin $\mathrm{C}(\mathrm{Vc})$ in food additives. The results showed that $\mathrm{Vc}$ increased cytotoxicity significantly compared with single ZnO NPs (Fig. 5a, b). Moreover, a significant increase in toxicity was also observed in in vivo experiments. Injury to the liver and kidney was detected after repeated oral exposure to ZnO NPs plus Vc in mice. However, another type of food additive, casein phosphopeptides (CPP), showed significant cytoprotective effects against cytotoxicity induced by single ZnO NPs (Fig. $5 \mathrm{c}-\mathrm{h}$ ) [135]. The cytotoxicity of $\mathrm{TiO}_{2}$ NPs seems far less affected in a complex system containing Vc or CPP. Based on these results, we can suggest that different MONPs show different toxicity change trends in different complex systems. The nanotoxicology of the complex system requires more attention to fill the gap of nanosafety study.

\section{CONCLUSIONS AND PERSPECTIVE}

In this review, we systematically summarized the toxicity effects of the most widely used MONPs both in vitro and in vivo. Many factors such as the size, shape, and surface chemical property have an influence on the toxicity of MONPs. Meanwhile, various exposure routes affect toxicity and bio-distribution in vivo. However, to date, determining the characteristics that are responsible for the hazardous nature of some NPs remains a huge challenge, and it is critical in determining the practical application of MONPs. The toxicity of MONPs remains debatable. The assays currently used for toxicity evaluation of IONPs are still not well adapted for these measurements, and many results are even published based on unreliable methods. Therefore, a unified methodology for toxicity evaluation of
MONPs needs to be developed further. Moreover, there are only very few reports on the combined effects of MONPs so far. The safety evaluation standards for MONPs used in commercial products are always set up based on the toxic effects of single MONPs alone. However, since size, chemical nature, and surface properties have a dramatic influence on the toxicity of nanomaterials, toxicity effect may change when MONPs are used in consumer products such as cosmetics, food, and environment. The results of combined toxicity in food show that the toxicity of $\mathrm{ZnO}$ NPs dramatically changed both in vitro and in vivo in different complex systems. However, $\mathrm{TiO}_{2} \mathrm{NPs}$, which are chemically inert, seems far less toxic, even in a complex system. Therefore, various MONPs show different toxicity change trends in different complex systems. For the safety assessment of MONPs used in commercial products, nanotoxicological study of the composite systems requires more efforts in the future.

Received 15 November 2016; accepted 3 January 2017; published online 17 January 2017

1 Dykman L, Khlebtsov N. Gold nanoparticles in biomedical applications: recent advances and perspectives. Chem Soc Rev, 2012, 41: 2256-2282

2 Wu QS, Liu JW, Wang GS, et al. A surfactant-free route to synthesize $\mathrm{Ba}_{x} \mathrm{Sr}_{1-x} \mathrm{TiO}_{3}$ nanoparticles at room temperature, their dielectric and microwave absorption properties. Sci China Mater, 2016, 59: $609-617$

3 Arvizo RR, Bhattacharyya S, Kudgus RA, et al. Intrinsic therapeutic applications of noble metal nanoparticles: past, present and future. Chem Soc Rev, 2012, 41: 2943

4 Llevot A, Astruc D. Applications of vectorized gold nanoparticles to the diagnosis and therapy of cancer. Chem Soc Rev, 2012, 41: 242-257

5 Sun Z, Liao T, Kou L. Strategies for designing metal oxide nanostructures. Sci China Mater, 2017, 60: 1-24

6 Rana S, Bajaj A, Mout R, et al. Monolayer coated gold nanoparticles for delivery applications. Adv Drug Deliver Rev, 2012, 64: 200-216

7 Lin X, Zuo YY, Gu N. Shape affects the interactions of nanoparticles with pulmonary surfactant. Sci China Mater, 2015, 58: 28-37

8 Colvin VL. The potential environmental impact of engineered nanomaterials. Nat Biotechnol, 2003, 21: 1166-1170

9 Zhao Y, Xing G, Chai Z. Nanotoxicology: are carbon nanotubes safe? Nat Nanotech, 2008, 3: 191-192

10 Hoet PHM, Nemmar A, Nemery B. Health impact of nanomaterials? Nat Biotechnol, 2004, 22: 19

11 Service RF. Nanomaterials show signs of toxicity. Science, 2003, 300: 243

12 Chen L, Remondetto GE, Subirade M. Food protein-based materials as nutraceutical delivery systems. Trends Food Sci Tech, 2006, 17: $272-283$

13 Donaldson K, Tran L, Jimenez LA, et al. Combustion-derived nanoparticles: a review of their toxicology following inhalation exposure. Part Fibre Toxicol, 2005, 2: 10

14 Cortie MB, McDonagh AM. Synthesis and optical properties of hybrid and alloy plasmonic nanoparticles. Chem Rev, 2011, 111: 
3713-3735

15 Yang F, Li M, Cui H, et al. Altering the response of intracellular reactive oxygen to magnetic nanoparticles using ultrasound and microbubbles. Sci China Mater, 2015, 58: 467-480

16 Koeneman BA, Zhang Y, Westerhoff $\mathrm{P}$, et al. Toxicity and cellular responses of intestinal cells exposed to titanium dioxide. Cell Biol Toxicol, 2010, 26: 225-238

17 Jani PU, McCarthy DE, Florence AT. Titanium dioxide (rutile) particle uptake from the rat GI tract and translocation to systemic organs after oral administration. Int J Pharm, 1994, 105: 157-168

18 Liu X, Zhang J, Tang S, et al. Growth enhancing effect of LBLassembled magnetic nanoparticles on primary bone marrow cells. Sci China Mater, 2016, 59: 901-910

19 Ning Z, Sillanpää M, Pakbin P, et al. Field evaluation of a new particle concentrator-electrostatic precipitator system for measuring chemical and toxicological properties of particulate matter. Part Fibre Toxicol, 2008, 5: 15

20 Wiesner MR, Lowry GV, Alvarez P, et al. Assessing the risks of manufactured nanomaterials. Environ Sci Technol, 2006, 40: 4336-4345

21 Chen JL, Fayerweather WE. Epidemiologic study of workers exposed to titanium dioxide. J Occupational Environ Med, 1988, 30: 937-942

22 Ghosh M, Chakraborty A, Mukherjee A. Cytotoxic, genotoxic and the hemolytic effect of titanium dioxide $\left(\mathrm{TiO}_{2}\right)$ nanoparticles on human erythrocyte and lymphocyte cells in vitro. J Appl Toxicol, 2013, 33: 1097-1110

23 Zhang J, Li S, Yang P, et al. Deposition of transparent $\mathrm{TiO}_{2}$ nanotubes-films via electrophoretic technique for photovoltaic applications. Sci China Mater, 2015, 58: 785-790

24 Magdolenova Z, Bilaničová D, Pojana G, et al. Impact of agglomeration and different dispersions of titanium dioxide nanoparticles on the human related in vitro cytotoxicity and genotoxicity. J Environ Monit, 2012, 14: 455-464

25 Thomas KV, Farkas J, Farmen E, et al. Effects of dispersed aggregates of carbon and titanium dioxide engineered nanoparticles on rainbow trout hepatocytes. J Toxicol Environ Health A, 2011, 74: 466-477

26 Sha BY, Gao W, Wang SQ, et al. Cytotoxicity of titanium dioxide nanoparticles differs in four liver cells from human and rat. Composites Part B-Eng, 2011, 42: 2136-2144

27 Pujalté I, Passagne I, Brouillaud B, et al. Cytotoxicity and oxidative stress induced by different metallic nanoparticles on human kidney cells. Part Fibre Toxicol, 2011, 8: 10

28 Botelho MC, Costa C, Silva S, et al. Effects of titanium dioxide nanoparticles in human gastric epithelial cells in vitro. Biomed Pharmacother, 2014, 68: 59-64

29 Butler KS, Casey BJ, Garborcauskas GVM, et al. Assessment of titanium dioxide nanoparticle effects in bacteria: association, uptake, mutagenicity, co-mutagenicity and DNA repair inhibition. Mutation Res/Genet Toxicol Environ Mutagenesis, 2014, 768: 14-22

30 Valdiglesias V, Costa C, Sharma V, et al. Comparative study on effects of two different types of titanium dioxide nanoparticles on human neuronal cells. Food Chem Toxicol, 2013, 57: 352-361

31 Wang Y, Yao C, Li C, et al. Excess titanium dioxide nanoparticles on the cell surface induce cytotoxicity by hindering ion exchange and disrupting exocytosis processes. Nanoscale, 2015, 7: 13105-13115

32 Yin Y, Zhu WW, Guo LP, et al. RGDC functionalized titanium dioxide nanoparticles induce less damage to plasmid DNA but higher cytotoxicity to HeLa cells. J Phys Chem B, 2013, 117: 125-131

33 Venkatasubbu GD, Ramasamy S, Avadhani GS, et al. Size-mediated cytotoxicity of nanocrystalline titanium dioxide, pure and zincdoped hydroxyapatite nanoparticles in human hepatoma cells. J Nanopart Res, 2012, 14: 819

34 Liang G, Pu Y, Yin L, et al. Influence of different sizes of titanium dioxide nanoparticles on hepatic and renal functions in rats with correlation to oxidative stress. J Toxicol Environ Health A, 2009, 72: $740-745$

35 Zhang Y, Yu W, Jiang X, et al. Analysis of the cytotoxicity of differentially sized titanium dioxide nanoparticles in murine MC3T3-E1 preosteoblasts. J Mater Sci-Mater Med, 2011, 22: 1933-1945

36 Xiong S, George S, Yu H, et al. Size influences the cytotoxicity of poly (lactic-co-glycolic acid) (PLGA) and titanium dioxide $\left(\mathrm{TiO}_{2}\right)$ nanoparticles. Arch Toxicol, 2013, 87: 1075-1086

37 Wang Y, Sui K, Fang J, et al. Cytotoxicity evaluation and subcellular location of titanium dioxide nanotubes. Appl Biochem Biotechnol, 2013, 171: 1568-1577

38 Wang Y, Wang J, Deng X, et al. Direct imaging of titania nanotubes located in mouse neural stem cell nuclei. Nano Res, 2009, 2: 543-552

39 Wang Y, Wu Q, Sui K, et al. A quantitative study of exocytosis of titanium dioxide nanoparticles from neural stem cells. Nanoscale, 2013, 5: 4737-4743

40 Tsuji JS, Maynard AD, Howard PC, et al. Research strategies for safety evaluation of nanomaterials, part IV: risk assessment of nanoparticles. Toxicol Sci, 2005, 89: 42-50

41 Lademann J, Weigmann HJ, Rickmeyer C, et al. Penetration of titanium dioxide microparticles in a sunscreen formulation into the horny layer and the follicular orifice. Skin Pharmacol Physiol, 1999, 12: 247-256

$42 \mathrm{Wu}$ J, Liu W, Xue C, et al. Toxicity and penetration of $\mathrm{TiO}_{2}$ nanoparticles in hairless mice and porcine skin after subchronic dermal exposure. Toxicol Lett, 2009, 191: 1-8

43 Hagens WI, Oomen AG, de Jong WH, et al. What do we (need to) know about the kinetic properties of nanoparticles in the body? Regul Toxicol Pharm, 2007, 49: 217-229

44 Namavar F, Cheung CL, Sabirianov RF, et al. Lotus effect in engineered zirconia. Nano Lett, 2008, 8: 988-996

$45 \mathrm{Li} \mathrm{J,} \mathrm{Li} \mathrm{Q,} \mathrm{Xu} \mathrm{J,} \mathrm{et} \mathrm{al.} \mathrm{Comparative} \mathrm{study} \mathrm{on} \mathrm{the} \mathrm{acute} \mathrm{pulmonary}$ toxicity induced by 3 and $20 \mathrm{~nm} \mathrm{TiO}$ primary particles in mice. Environ Toxicol Pharmacol, 2007, 24: 239-244

46 Liu R, Yin L, Pu Y, et al. Pulmonary toxicity induced by three forms of titanium dioxide nanoparticles via intra-tracheal instillation in rats. Prog Nat Sci, 2009, 19: 573-579

47 Hamilton RF, Wu N, Porter D, et al. Particle length-dependent titanium dioxide nanomaterials toxicity and bioactivity. Part Fibre Toxicol, 2009, 6: 35

48 Chen XX, Cheng B, Yang YX, et al. Characterization and preliminary toxicity assay of nano-titanium dioxide additive in sugarcoated chewing gum. Small, 2013, 9: 1765-1774

49 Wang Y, Chen Z, Ba T, et al. Susceptibility of young and adult rats to the oral toxicity of titanium dioxide nanoparticles. Small, 2013, 9: 1742-1752

50 Fang J, Yuan LL, Yao CJ, et al. Biodistribution and toxicity study of titanium dioxide nanoparticles of different sizes after intravenous injection in mice. Adv Mater Res, 2014, 998-999: 196-199

51 Yao C, Li C, Ding L, et al. Effects of exposure routes on the biodistribution and toxicity of titanium dioxide nanoparticles in mice. J Nanosci Nanotechnol, 2016, 16: 7110-7117

52 Zhang J, Lang HP, Huber F, et al. Rapid and label-free nanomechanical detection of biomarker transcripts in human RNA. Nat Nanotech, 2006, 1: 214-220

53 Dunphy Guzmán KA, Taylor MR, Banfield JF. Environmental risks 
of nanotechnology: National Nanotechnology Initiative Funding, 2000-2004. Environ Sci Technol, 2006, 40: 1401-1407

$54 \mathrm{He} \mathrm{W}, \mathrm{Wu} \mathrm{H}, \mathrm{Wamer} \mathrm{WG}$, et al. Unraveling the enhanced photocatalytic activity and phototoxicity of $\mathrm{ZnO} /$ metal hybrid nanostructures from generation of reactive oxygen species and charge carriers. ACS Appl Mater Interfaces, 2014, 6: 15527-15535

55 Wissing SA, Müller RH. Solid lipid nanoparticles (SLN) - a novel carrier for UV blockers. Die Pharmazie, 2001, 56: 783-786

56 Zhang Y, Kang Z, Yan X, et al. ZnO nanostructures in enzyme biosensors. Sci China Mater, 2015, 58: 60-76

57 Chen S, Lou Z, Chen D, et al. Highly flexible strain sensor based on $\mathrm{ZnO}$ nanowires and $\mathrm{P}(\mathrm{VDF}-\mathrm{TrFE})$ fibers for wearable electronic device. Sci China Mater, 2016, 59: 173-181

58 Wang Y, Yuan L, Yao C, et al. A combined toxicity study of zinc oxide nanoparticles and vitamin $\mathrm{C}$ in food additives. Nanoscale, 2014, 6: 15333-15342

59 Mortimer M, Kasemets $\mathrm{K}$, Kahru A. Toxicity of $\mathrm{ZnO}$ and $\mathrm{CuO}$ nanoparticles to ciliated protozoa Tetrahymena thermophila. Toxicol, 2010, 269: 182-189

60 Suh KS, Lee YS, Seo SH, et al. Effect of zinc oxide nanoparticles on the function of MC3T3-E1 osteoblastic cells. Biol Trace Elem Res, 2013, 155: 287-294

61 Xu M, Fujita D, Kajiwara S, et al. Contribution of physicochemical characteristics of nano-oxides to cytotoxicity. Biomaterials, 2010, 31: 8022-8031

62 Chen R, Huo L, Shi X, et al. Endoplasmic reticulum stress induced by zinc oxide nanoparticles is an earlier biomarker for nanotoxicological evaluation. ACS Nano, 2014, 8: 2562-2574

63 Moos PJ, Chung K, Woessner D, et al. ZnO particulate matter requires cell contact for toxicity in human colon cancer cells. Chem Res Toxicol, 2010, 23: 733-739

64 Sahu D, Kannan GM, Vijayaraghavan R. Size-dependent effect of zinc oxide on toxicity and inflammatory potential of human monocytes. J Toxicol Environ Health A, 2014, 77: 177-191

65 Yin $\mathrm{H}$, Casey PS, McCall MJ. Surface modifications of $\mathrm{ZnO}$ nanoparticles and their cytotoxicity. J Nanosci Nanotech, 2010, 10: 7565-7570

66 Gilbert E, Pirot F, Bertholle V, et al. Commonly used UV filter toxicity on biological functions: review of last decade studies. Int $\mathrm{J}$ Cosmet Sci, 2013, 35: 208-219

67 Cross SE, Innes B, Roberts MS, et al. Human skin penetration of sunscreen nanoparticles: in-vitro assessment of a novel micronized zinc oxide formulation. Skin Pharmacol Physiol, 2007, 20: 148-154

68 Filipe P, Silva JN, Silva R, et al. Stratum corneum is an effective barrier to $\mathrm{TiO}_{2}$ and $\mathrm{ZnO}$ nanoparticle percutaneous absorption. Skin Pharmacol Physiol, 2009, 22: 266-275

69 Jang YS, Lee EY, Park YH, et al. The potential for skin irritation, phototoxicity, and sensitization of $\mathrm{ZnO}$ nanoparticles. Mol Cell Toxicol, 2012, 8: 171-177

70 Prasad AS. Clinical, immunological, anti-inflammatory and antioxidant roles of zinc. Exp Gerontology, 2008, 43: 370-377

71 Rincker MJ, Hill GM, Link JE, et al. Effects of dietary iron supplementation on growth performance, hematological status, and whole-body mineral concentrations of nursery pigs. J Anim Sci, 2004, 82: 3189-3197

72 Sharma V, Singh P, Pandey AK, et al. Induction of oxidative stress, DNA damage and apoptosis in mouse liver after sub-acute oral exposure to zinc oxide nanoparticles. Mutation Res-Genet Tox En, 2012, 745: 84-91

73 Ko JW, Hong ET, Lee IC, et al. Evaluation of 2-week repeated oral dose toxicity of $100 \mathrm{~nm}$ zinc oxide nanoparticles in rats. Lab Anim Res, 2015, 31: 139-147
74 Nie Z, Wang $\mathrm{Y}$, Zhang $\mathrm{Y}$, et al. Multi-shelled $\alpha-\mathrm{Fe}_{2} \mathrm{O}_{3}$ microspheres for high-rate supercapacitors. Sci China Mater, 2016, 59: 247-253

75 Li W, Feng X, Liu D, et al. In situ redox strategy for large-scale fabrication of surfactant-free $\mathrm{M}-\mathrm{Fe}_{2} \mathrm{O}_{3}(\mathrm{M}=\mathrm{Pt}, \mathrm{Pd}, \mathrm{Au})$ hybrid nanospheres. Sci China Mater, 2016, 59: 191-199

76 Ling D, Hyeon T. Chemical design of biocompatible iron oxide nanoparticles for medical applications. Small, 2013, 9: 1450-1466

77 Veiseh O, Gunn JW, Zhang M. Design and fabrication of magnetic nanoparticles for targeted drug delivery and imaging. Adv Drug Deliver Rev, 2010, 62: 284-304

78 Laurent S, Forge D, Port M, et al. Magnetic iron oxide nanoparticles: synthesis, stabilization, vectorization, physicochemical characterizations, and biological applications. Chem Rev, 2008, 108: 2064-2110

79 Cai H, An X, Cui J, et al. Facile hydrothermal synthesis and surface functionalization of polyethyleneimine-coated iron oxide nanoparticles for biomedical applications. ACS Appl Mater Interfaces, 2013, 5: 1722-1731

80 Berry CC, Wells S, Charles S, et al. Cell response to dextran-derivatised iron oxide nanoparticles post internalisation. Biomaterials, 2004, 25: 5405-5413

81 Stroh A, Zimmer C, Gutzeit C, et al. Iron oxide particles for molecular magnetic resonance imaging cause transient oxidative stress in rat macrophages. Free Radical Biol Med, 2004, 36: 976-984

82 Pawelczyk E, Arbab AS, Chaudhry A, et al. In vitro model of bromodeoxyuridine or iron oxide nanoparticle uptake by activated macrophages from labeled stem cells: implications for cellular therapy. Stem Cells, 2008, 26: 1366-1375

83 Siglienti I, Bendszus M, Kleinschnitz C, et al. Cytokine profile of iron-laden macrophages: implications for cellular magnetic resonance imaging. J Neuroimmunol, 2006, 173: 166-173

84 Mahmoudi M, Simchi A, Imani M, et al. An in vitro study of bare and poly(ethylene glycol)-co-fumarate-coated superparamagnetic iron oxide nanoparticles: a new toxicity identification procedure. Nanotechnology, 2009, 20: 225104

85 Huang G, Diakur J, Xu Z, et al. Asialoglycoprotein receptor-targeted superparamagnetic iron oxide nanoparticles. Int J Pharm, 2008, 360: 197-203

86 Naqvi S, Samim M, Abdin M, et al. Concentration-dependent toxicity of iron oxide nanoparticles mediated by increased oxidative stress. Int J Nanomedicine, 2010, 5: 983-989

87 Kunzmann A, Andersson B, Vogt C, et al. Efficient internalization of silica-coated iron oxide nanoparticles of different sizes by primary human macrophages and dendritic cells. Toxicol Appl Pharmacol, 2011, 253: 81-93

88 Karlsson HL, Cronholm P, Gustafsson J, et al. Copper oxide nanoparticles are highly toxic: a comparison between metal oxide nanoparticles and carbon nanotubes. Chem Res Toxicol, 2008, 21: 1726-1732

89 Hussain SM, Hess KL, Gearhart JM, et al. In vitro toxicity of nanoparticles in BRL 3A rat liver cells. Toxicol in Vitro, 2005, 19: 975-983

90 Hohnholt MC, Dringen R. Uptake and metabolism of iron and iron oxide nanoparticles in brain astrocytes. Biochm Soc Trans, 2013, 41: 1588-1592

$91 \mathrm{Gu} \mathrm{L}$, Fang RH, Sailor MJ, et al. In vivo clearance and toxicity of monodisperse iron oxide nanocrystals. ACS Nano, 2012, 6: 4947-4954

92 Zhu MT, Feng WY, Wang Y, et al. Particokinetics and extrapulmonary translocation of intratracheally instilled ferric oxide nanoparticles in rats and the potential health risk assessment. Toxicol Sci, 2008, 107: 342-351 
93 Bellusci M, La Barbera A, Padella F, et al. Biodistribution and acute toxicity of a nanofluid containing manganese iron oxide nanoparticles produced by a mechanochemical process. Int J Nanomed, 2014, 9: 1919-1929

94 Gupta AK, Gupta M. Synthesis and surface engineering of iron oxide nanoparticles for biomedical applications. Biomaterials, 2005, 26: 3995-4021

95 Mahmoudi M, Hofmann H, Rothen-Rutishauser B, et al. Assessing the in vitro and in vivo toxicity of superparamagnetic iron oxide nanoparticles. Chem Rev, 2012, 112: 2323-2338

96 Zhang YQ, Dringen R, Petters C, et al. Toxicity of dimercaptosuccinate-coated and un-functionalized magnetic iron oxide nanoparticles towards aquatic organisms. Environ Sci-Nano, 2016, 3: 754-767

97 Zhu MT, Feng WY, Wang B, et al. Comparative study of pulmonary responses to nano- and submicron-sized ferric oxide in rats. Toxicology, 2008, 247: 102-111

98 Di Bona KR, Xu Y, Ramirez PA, et al. Surface charge and dosage dependent potential developmental toxicity and biodistribution of iron oxide nanoparticles in pregnant CD-1 mice. Reprod Toxicol, 2014, 50: 36-42

99 Hanini J, Schmitt J, Kacem K, et al. Evaluation of iron oxide nanoparticle biocompatibility. Int J Nanomedicine, 2011, 6: 787-794

100 Sun T, Yan Y, Zhao Y, et al. Copper oxide nanoparticles induce autophagic cell death in A549 cells. PLoS ONE, 2012, 7: e43442

101 Dong E, Wang Y, Yang ST, et al. Toxicity of nano gamma alumina to neural stem cells. J Nanosci Nanotech, 2011, 11: 7848-7856

102 Chattopadhyay S, Dash SK, Tripathy S, et al. Toxicity of cobalt oxide nanoparticles to normal cells an in vitro and in vivo study. Chemico-Biol Interactions, 2015, 226: 58-71

103 Ates M, Demir V, Arslan Z, et al. Toxicity of engineered nickel oxide and cobalt oxide nanoparticles to Artemia salina in seawater. Water Air Soil Pollut, 2016, 227: 70

104 Tedesco S, Doyle H, Blasco J, et al. Oxidative stress and toxicity of gold nanoparticles in Mytilus edulis. Aquatic Toxicol, 2010, 100: $178-186$

105 Zhuang W, Gao X. Methods, mechanisms and typical bio-indicators of engineered nanoparticle ecotoxicology: an overview. Clean Soil Air Water, 2014, 42: 377-385

106 Ray PD, Huang BW, Tsuji Y. Reactive oxygen species (ROS) homeostasis and redox regulation in cellular signaling. Cellular Signalling, 2012, 24: 981-990

107 Huang YW, Wu CH, Aronstam RS. Toxicity of transition metal oxide nanoparticles: recent insights from in vitro studies. Materials, 2010, 3: 4842-4859

108 Mocan T, Clichici S, Agoşton-Coldea L, et al. Implications of oxidative stress mechanisms in toxicity of nanoparticles. Acta Physiol Hung, 2010, 97: 247-255

109 Risom L, Møller P, Loft S. Oxidative stress-induced DNA damage by particulate air pollution. Mutat Res-Fund Mol M, 2005, 592: 119-137

110 Xiong D, Fang T, Yu L, et al. Effects of nano-scale $\mathrm{TiO}_{2}, \mathrm{ZnO}$ and their bulk counterparts on zebrafish: acute toxicity, oxidative stress and oxidative damage. Sci Total Environ, 2011, 409: 1444-1452

111 Knaapen AM, Borm PJA, Albrecht C, et al. Inhaled particles and lung cancer. Part A: mechanisms. Int J Cancer, 2004, 109: 799-809

112 Horie M, Komaba LK, Kato H, et al. Evaluation of cellular influences induced by stable nanodiamond dispersion the cellular influences of nanodiamond are small. Diamond Related Mater, 2012, 24: $15-24$

113 Sharma V, Anderson D, Dhawan A. Zinc oxide nanoparticles in- duce oxidative DNA damage and ROS-triggered mitochondria mediated apoptosis in human liver cells (HepG2). Apoptosis, 2012, 17: $852-870$

114 Li N, Duan Y, Hong M, et al. Spleen injury and apoptotic pathway in mice caused by titanium dioxide nanoparticules. Toxicol Lett, 2010, 195: 161-168

115 Cho Y, Gorina S, Jeffrey PD, et al. Crystal structure of a p53 tumor suppressor-DNA complex: understanding tumorigenic mutations. Science, 1994, 265: 346-355

116 Basu A. The relationship between $\mathrm{BcI} 2$, Bax and p53: consequences for cell cycle progression and cell death. Mol Human Reprod, 1998, 4: 1099-1109

117 Haldar S, Negrini M, Monne M, et al. Down-regulation of bcl-2 by p53 in breast cancer cells. Cancer Res, 1994, 54: 2095-2097

118 Chipuk JE, Kuwana T, Bouchier-Hayes L, et al. Direct activation of Bax by 53 mediates mitochondrial membrane permeabilization and apoptosis. Science, 2004, 303: 1010-1014

119 Antonsson B. Inhibition of Bax channel-forming activity by Bcl-2. Science, 1997, 277: 370-372

120 Song MF, Li YS, Kasai H, et al. Metal nanoparticle-induced micronuclei and oxidative DNA damage in mice. J Clin Biochem Nutr, 2012, 50: 211-216

121 Zaffaroni N, Pannati M, Diadone MG. Survivin as a target for new anticancer interventions. J Cellular Mol Med, 2005, 9: 360-372

122 Fadeel B, Orrenius S. Apoptosis: a basic biological phenomenon with wide-ranging implications in human disease. J Intern Med, 2005, 258: 479-517

123 Manke A, Wang L, Rojanasakul Y. Mechanisms of nanoparticleinduced oxidative stress and toxicity. BioMed Res Int, 2013, 2013: $1-15$

124 Lankoff A, Sandberg WJ, Wegierek-Ciuk A, et al. The effect of agglomeration state of silver and titanium dioxide nanoparticles on cellular response of HepG2, A549 and THP-1 cells. Toxicol Lett, 2012, 208: 197-213

125 Prasad RY, Simmons SO, Killius MG, et al. Cellular interactions and biological responses to titanium dioxide nanoparticles in HepG2 and BEAS-2B cells: role of cell culture media. Environ $\mathrm{Mol}$ Mutagen, 2014, 55: 336-342

126 Li L, Jiang LL, Zeng Y, et al. Toxicity of superparamagnetic iron oxide nanoparticles: research strategies and implications for nanomedicine. Chin Phys B, 2013, 22: 127503

127 Rousk J, Ackermann K, Curling SF, et al. Comparative toxicity of nanoparticulate $\mathrm{CuO}$ and $\mathrm{ZnO}$ to soil bacterial communities. PLoS ONE, 2012, 7: e34197

128 Zhang ZY, Xiong HM. Photoluminescent ZnO nanoparticles and their biological applications. Materials, 2015, 8: 3101-3127

129 Franklin NM, Rogers NJ, Apte SC, et al. Comparative toxicity of nanoparticulate $\mathrm{ZnO}$, Bulk $\mathrm{ZnO}$, and $\mathrm{ZnCl}_{2}$ to a freshwater microalga (Pseudokirchneriella subcapitata): the importance of particle solubility. Environ Sci Technol, 2007, 41: 8484-8490

130 Adrain C, Creagh EM, Martin SJ. Defying death: showing Bcl-2 the way home. Nat Cell Biol, 2003, 5: 9-11

131 Zhao J, Bowman L, Zhang $\mathrm{X}$, et al. Titanium dioxide $\left(\mathrm{TiO}_{2}\right)$ nanoparticles induce JB6 cell apoptosis through activation of the caspase-8/Bid and mitochondrial pathways. J Toxicol Environ Health A, 2009, 72: 1141-1149

132 Cui Y, Liu H, Zhou M, et al. Signaling pathway of inflammatory responses in the mouse liver caused by $\mathrm{TiO}_{2}$ nanoparticles. J Biomed Mater Res, 2011, 96A: 221-229

133 Tong T, Fang K, Thomas SA, et al. Chemical interactions between nano- $\mathrm{ZnO}$ and nano- $\mathrm{TiO}_{2}$ in a natural aqueous medium. Environ Sci Technol, 2014, 48: 7924-7932 
134 Tong T, Wilke CM, Wu J, et al. Combined toxicity of nano- $\mathrm{ZnO}$ and nano- $\mathrm{TiO}_{2}$ : from single- to multinanomaterial systems. Environ Sci Technol, 2015, 49: 8113-8123

135 Wang Y, Yuan L, Yao C, et al. Caseinophosphopeptides cytoprotect human gastric epithelium cells against the injury induced by zinc oxide nanoparticles. RSC Adv, 2014, 4: 42168-42174

Acknowledgments This work was supported by the National Natural Science Foundation of China (21371115, 11025526, 40830744, 41073073, and 21101104), the National Basic Research Program of China
(2011CB933402), the Innovation Program of Shanghai Municipal Education Commission (14YZ025), and the Program for Innovative Research Team in University (IRT13078).

Author contributions Wang $\mathrm{Y}, \mathrm{Wu} \mathrm{M}$ and Ding $\mathrm{L}$ organized the references and wrote the paper. Ding L, Yao C, Li C, Xing X, Huang Y and $\mathrm{Gu} \mathrm{T}$ finished the literature investigation. Ding $\mathrm{L}$ took the leadership of the literature investigation and organized the figures. All authors discussed the idea of the paper.

Conflict of interest The authors declare that they have no conflict of interest.

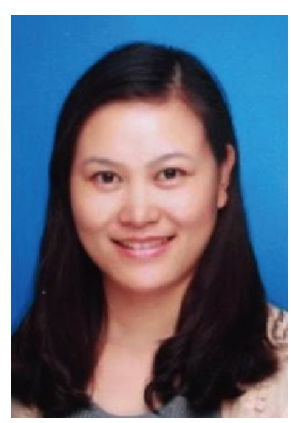

Yanli Wang is now working at the Institute of Nanochemistry and Nanobiology of Shanghai University as an associate professor since 2012. She obtained her PhD degree in environmental engineering from Shanghai University in 2010. Her research interests include bio-effects and safety evaluation of nanomaterials and their application in bio-imaging and cancer therapy.

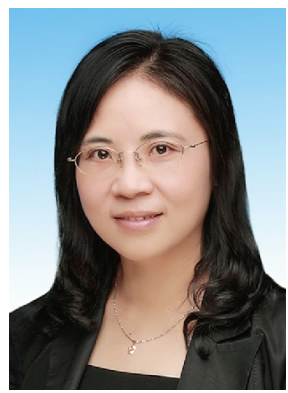

Minghong Wu obtained her PhD degree from Shanghai Institute of Applied Physics of Chinese Academy of Sciences in 1999. She is the National outstanding youth and Yangtze River scholar of China. Based on her scientific contribution, she was selected as the Russian Academy of foreign academicians of Russian Academy of Engineering in 2008 and Russian Academy of Science in 2015. Her research interests mainly focus on bio-effects and safety evaluation of nanomaterials and environmental pollution analysis and control.

\section{金属氧化物纳米颗粒生物毒性效应及毒性机理研究进展 \\ 王艳丽 ${ }^{1,2}$, 丁琳 ${ }^{1}$, 姚晨婕 ${ }^{1}$, 李晨晨 ${ }^{1}$, 邢晓军 ${ }^{1}$, 黄雅男 ${ }^{1}$, 顾天骄 ${ }^{1}$, 吴明红 ${ }^{1 *}$}

摘要 纳米材料由于其独特的性质已经被广泛应用于很多领域, 但随着纳米材料的大规模制备和广泛应用, 它对环境以及人类的潜在危害 越来越引起人们的重视. 金属氧化物纳米颗粒(MONPs)作为一类纳米材料大量地用于食品、医药、化妆品、传感器等领域. 因此, MONPs 的生物毒性研究至关重要. 本文主要对目前应用最为广泛的几种MONPs (纳米二氧化钛、氧化锌、氧化铁等)生物毒性的研究及其毒性机 理做了总结. MONPs 导致毒性的机制有两个方面: ROS介导的毒性和非ROS介导的毒性. ROS激活氧化应激, 导致脂质过氧化, 引起细胞膜 损伤, 此外, ROS可以激活 caspase-9和caspase-3, 触发调亡通路. 非ROS介导的毒性机制, 包括MONPs释放的离子引起的毒性, 纳米粒子在细 胞表面的粘附以及与特定的死亡受体的相互作用. 此外, 由于当纳米材料处于一个复杂的体系中时, 它自身的性质,包括尺寸、粒径、表面 化学性质等都会发生变化, 我们对一些MONPs的复合毒性也做了讨论. 